\title{
Tributação das Transações Financeiras: a Experiência Brasileira com o IOF e a CPMF*
}

\section{Financial Transaction Taxes: the Brazilian Experience with IOF and CPMF}

\author{
Rafael Fagundes Cagnin** \\ Maria Cristina Penido de Freitas***
}

\begin{abstract}
Resumo: Este artigo tem como objetivo contribuir com um debate sobre tributação das transações financeiras mediante a análise da experiência brasileira. No Brasil, esse tipo de tributo se mostra importante tanto para a ampliação da capacidade de intervenção governamental no mercado financeiro quanto para o aumento da arrecadação associada ao fechamento de brechas para evasão fiscal. Contrariamente ao sustentado por seus críticos, esses tributos não impediram o aprofundamento financeiro da economia.
\end{abstract}

Palavras-chave: Tributação. Transações financeiras. Fluxos financeiros. Regulação. Brasil.

\begin{abstract}
This paper aims to subscribe to the debate on financial transactions taxation by the analysis of the Brazilian experience. In Brazil, this kind of tribute was important for both increasing the capacity of government intervention in financial markets and to narrow tax evasion. Contrary to the assertions by its critics, this kind of taxes has not prevented the financial deepening of the Brazilian economy.
\end{abstract}

Keywords: Taxing. Financial transactions taxes. Capital flows. Regulation. Brazil.

JEL Classification: E61; F41; G18.

\footnotetext{
* $\quad$ Este artigo, derivado de pesquisa realizada a pedido da Comissão Econômica para a América Latina e o Caribe (Cepal), foi concluído em dezembro de 2011 e apresenta os dados e informações disponíveis à época. Os autores agradecem os comentários de Marcos Antônio Macedo Cintra (Ipea), Mariana R. Jansen Ferreira (PUC-SP) e do parecerista anônimo.

* $\quad$ Mestre em Teoria Econômica pela Universidade Estadual de Campinas (Unicamp). Economista da Fundação para o Desenvolvimento Administrativo do Estado de São Paulo (Fundap/SP). E-mail: rcagnin@fundap.sp.gov.br

*** Doutora em Economia pela Universidade de Paris 13, pesquisadora associada do Centro de Estudos de Conjuntura e Política Econômica do Instituto de Economia da Unicamp (Cecon-IE/Unicamp) e do Grupo de Moeda, Crédito e Desenvolvimento da PUC-SP. E-mail: crispenido@uol. com.br
} 


\section{Introdução}

A crise internacional de 2008-2009 e os vultosos pacotes de socorro financeiro aos bancos nas economias desenvolvidas reacenderam o debate sobre a tributação das transações financeiras, mediante a imposição de uma taxa Tobin ${ }^{1}$ sobre os fluxos internacionais, seja com o intuito de reduzir as especulações nos mercados de moeda, seja com o intuito de recuperação dos gastos governamentais decorrentes da crise. No Brasil, um dos poucos países com larga experiência de tributação de transações financeiras, esse tipo de imposto contribuiu tanto para a ampliação da capacidade de intervenção governamental em mercados inerentemente instáveis, como é o caso do mercado financeiro, quanto para o aumento da arrecadação associada ao fechamento de brechas para evasão fiscal.

A experiência brasileira com a taxação de transações financeiras pode ser analisada a partir do Imposto sobre Operações Financeiras (IOF) e da Contribuição Provisória sobre Movimentações Financeiras (CPMF). Apesar de ambos incidirem sobre transações financeiras, os seus objetivos são distintos, assim como o contexto de criação de cada um deles. Enquanto o IOF foi criado como um instrumento auxiliar da política monetária, com incidência sobre um conjunto amplo de operações, inclusive aquelas realizadas por investidores estrangeiros, a CPMF constitui um tipo particular de tributação de transações financeiras (financial transaction taxes), incidente sobre operações financeiras domésticas e com um objetivo arrecadatório. Diferentemente de outros tributos sobre transações financeiras, como o IOF e a taxa Tobin, cujo objetivo principal é coibir comportamentos considerados indesejáveis nos mercados financeiros, a tributação do tipo bank debit taxes, como a CPMF, buscaria elevar a arrecadação sem gerar impactos importantes sobre as decisões dos agentes econômicos. ${ }^{2}$

Este artigo tem como objetivo contribuir para o debate sobre tributação das transações financeiras mediante a análise da experiência brasileira. Com esse propósito, está organizado da seguinte maneira: após esta breve introdução será recuperado, na seção 2, o contexto histórico da criação tanto do IOF quanto da CPMF. Em ambos os casos, buscou-se enfatizar os objetivos almejados com a criação de cada uma dessas tributações; na seção 3, discutem-se os papéis adicionais desempenhados por estes tributos: gestão dos fluxos de capitais e instrumento de política

1 A taxa Tobin consiste na cobrança de um imposto sobre transações cambiais em âmbito global. Foi proposta pela primeira vez em 1972 pelo economista James Tobin, segundo o qual a aplicação de uma pequena alíquota sobre operações cambiais com objetivos especulativos poderia aumentar os graus de liberdade da política monetária em países com regime de câmbio flutuante. Em meados da década de 2000, a capacidade arrecadatória da taxa do tipo Tobin passou a ser enfatizada. Ver, por exemplo, Schutte (2010). bank debit taxes em países latino-americanos, ver Coelho et al. (2001). 
financeira no caso do IOF, no final da década de 2000, com seu caráter macroprudencial reforçado a partir do início de 2011, e instrumento importante de combate à sonegação fiscal no caso da CPMF, a partir de 2001; para finalizar, na seção 4 são apresentadas as considerações finais.

\section{Os Contextos Históricos da Criação do IOF e da CPMF}

\subsection{Instituição do IOF como Imposto Regulatório}

Criado pelo regime militar na ocasião da reforma tributária de $1966,{ }^{3}$ o imposto sobre as operações financeiras (IOF) foi concebido como instrumento auxiliar das políticas monetária e cambial na perseguição dos objetivos macroeconômicos estabelecidos pelo governo federal. O financiamento dos gastos públicos não é sua função principal. Trata-se, então, de um imposto extrafiscal ou regulatório, em que a arrecadação tributária decorrente consiste apenas em um efeito secundário.

O caráter regulatório do IOF está expresso no Código Tributário, Seção IV, Artigo 65: "O Poder Executivo pode, nas condições e nos limites estabelecidos em lei, alterar as alíquotas ou as bases de cálculo do imposto, a fim de ajustá-lo aos objetivos de política monetária”. Reforçava esse caráter o fato de que as receitas obtidas não compunham o Orçamento da União, mas eram direcionadas a um fundo denominado de "Reservas Monetárias" e eram usadas pelo Banco Central do Brasil (BCB) em intervenções nos mercados de câmbio e de títulos e no provimento de liquidez a instituições financeiras (BARBOSA, [201-?]; TORRES et al., 2003).

Em 1981, contudo, o BCB perdeu sua exclusividade sobre as receitas do IOF. Nesse ano, metade da arrecadação do imposto passou a integrar o Fundo Nacional de Desenvolvimento (FND). No ano seguinte, o FND se apropriou da integralidade da receita do IOF. Finalmente, a partir da Constituição de 1988, o IOF deixou de ter uma destinação específica, passando a ser um recurso ordinário do Tesouro Nacional, ou seja, receita arrecadada sem vinculação que está à disposição do Tesouro para a execução do orçamento, conforme a alocação das despesas. Mesmo após essas mudanças, seu caráter regulatório foi mantido, expressando-se em uma participação na receita do Tesouro relativamente baixa e volátil, segundos os objetivos de política monetária e cambial.

O leque de operações sobre as quais incide o IOF foi progressivamente ampliado à medida que se desenvolviam os mercados financeiros domésticos. Em 1966, o artigo $1^{\circ}$ da Lei $n^{\circ} 5.143$ previa a incidência do IOF apenas sobre as operações de crédito e seguro realizadas por instituições financeiras e seguradoras. Com

3 A análise da reforma tributária de 1965 e discussão dos seus objetivos e resultados ultrapassam os propósitos desse artigo. Sobre esse ponto, ver Lopreato (1981) e Oliveira (2010). 
o Decreto-Lei $\mathrm{n}^{\circ} 1.783$ de 1980 a base de incidência do imposto passou a incluir operações de câmbio, transações com títulos e valores mobiliários, seguros de vida, de bens e de valores, empréstimos de qualquer natureza, abertura de crédito e descontos de títulos. A Constituição de 1988 incorporou ainda a tributação das operações com ouro - estabelecida em 1981 pela Lei $n^{\circ} 7.766$ - quando este fosse definido como ativo financeiro ou instrumento cambial, Atualmente, o conjunto das operações financeiras que estão especificadas na legislação, funcionando como base de incidência do IOF, agrega, assim, as operações de crédito, títulos e valores imobiliários, seguro, câmbio e ouro-ativo financeiro, às quais se somaram as operações com derivativos, a partir da Medida Provisória $n^{\circ} 539$ de julho de $2011^{4}$ (TORRES et al., 2003; MUNHOZ; SILVA, 2011).

As alíquotas de IOF incidentes sobre cada uma dessas operações especificadas têm valores máximos definidos segundo o Quadro 1. Limitado a esses valores, o governo federal pode manipular as alíquotas do imposto sobre as diferentes operações financeiras, de maneira a influenciar o comportamento dos agentes econômicos e a produzir os efeitos buscados pela política econômica. Por essa razão, as alíquotas efetivamente aplicadas sofreram inúmeras variações desde a criação do imposto, o que dificulta o acompanhamento de sua evolução histórica.

Quadro 1 - Alíquotas máximas de IOF

\begin{tabular}{|l|l|l|}
\hline $\begin{array}{l}\text { Natureza da } \\
\text { operação }\end{array}$ & Alíquota máxima & Alíquota vigente no final de 201 1* \\
\hline Crédito & $\begin{array}{l}1,5 \% \text { ao dia } \\
\text { sobre o valor da } \\
\text { operação** }\end{array}$ & $\begin{array}{l}\text { a) } 0,00137 \% \text { ou } 0,0041 \% \text { ao dia para ope- } \\
\text { rações de crédito com pessoa jurídica; } \\
\text { b) } 0,0068 \% \text { ao dia e adicional de } 0,38 \% \\
\text { para operações com pessoa física. }\end{array}$ \\
\hline $\begin{array}{l}\text { Operações } \\
\text { com títulos } \\
\text { e valores } \\
\text { mobiliários }\end{array}$ & $1,5 \%$ ao dia & $\begin{array}{l}\text { a) } 1,5 \% \text { ao dia para as aplicações feitas } \\
\text { por investidores estrangeiros em quotas } \\
\text { de fundo mútuo de investimento em em- } \\
\text { presas emergentes e em quotas de fundo } \\
\text { de investimento imobiliário (limitada a } \\
5 \% \text { para fundos regulares e até um ano } \\
\text { da data do registro das quotas na CVM } \\
\text { e limitada a 10\% para os fundos sem } \\
\text { funcionamento regular); } \\
\text { b) 0,5\% no resgate de quotas de fundos } \\
\text { de investimento antes de completado o } \\
\text { prazo de carência para crédito de rendi- } \\
\text { mentos. }\end{array}$ \\
\hline
\end{tabular}

continua...

$4 \quad$ A Medida Provisória $\mathrm{n}^{\circ} 539$ foi convertida na Lei $\mathrm{n}^{\circ} 12.543$, aprovada pelo Congresso e sancionada pela presidente da República em 8 de dezembro de 2011. 


\begin{tabular}{|l|l|l|}
\hline $\begin{array}{l}\text { Nonclusão. } \\
\text { operação }\end{array}$ & Aliquota máxima & Aliquota vigente no final de 201 1* \\
\hline Câmbio & $\begin{array}{l}\text { 25\% sobre o valor } \\
\text { da operação }\end{array}$ & $\begin{array}{l}\text { 0,38\% sobre o valor da operação. Certos } \\
\text { tipos de operação têm alíquotas diferen- } \\
\text { ciadas. }\end{array}$ \\
\hline Seguro & $\begin{array}{l}\text { 25\% sobre valor da } \\
\text { operação }\end{array}$ & $\begin{array}{l}\text { a) } 0 \% \text { nos casos de operações de resse- } \\
\text { guro, seguro obrigatório para financia- } \\
\text { mento habitacional, seguro de crédito à } \\
\text { exportação, etc.; } \\
\text { b) } 0,38 \% \text { sobre valor da operação para } \\
\text { seguros de vida, de acidentes pessoais e } \\
\text { de trabalho etc.; } \\
\text { c) 2,38\% sobre o valor da operação para } \\
\text { seguros privados de assistência de saúde; } \\
\text { d) 7,38\% sobre o valor das demais oper- } \\
\text { ações de seguro. }\end{array}$ \\
\hline Derivativos & $\begin{array}{l}25 \% \text { sobre valor da } \\
\text { operação }\end{array}$ & $\begin{array}{l}\text { 1\% sobre as posições líquidas vendidas } \\
\text { em derivativos cambiais acima de US\$ } 10 \\
\text { milhões. }\end{array}$ \\
\hline $\begin{array}{l}\text { Ouro (ativo } \\
\text { financeiro) }\end{array}$ & $\begin{array}{l}1 \% \text { sobre o valor da } \\
\text { operação }\end{array}$ & \begin{tabular}{l} 
1\% sobre o valor da operação. \\
\hline
\end{tabular} \\
\hline
\end{tabular}

Fonte: Elaboração própria a partir de Brasil (2007, 2011 [2012b]).

Notas: *Para informações detalhadas sobre alíquotas excepcionais e isenções e alíquotas zero incidentes sobre determinadas operações, consultar o Decreto $n^{\circ}$ 6.306/2007 e alterações posteriores; * "Quando não ficar definido o valor do principal a ser utilizado pelo tomador, a base de cálculo é o somatório dos saldos devedores diários apurado no último dia de cada mês. Quando ficar definido o valor do principal, a base de cálculo é o principal colocado à disposição do tomador, ou quando previsto mais de um pagamento, o valor do principal de cada uma das parcelas.

Em função de sua natureza regulatória, o volume total de arrecadação do IOF não chega a ser expressivo. Em 2007, o IOF obteve uma receita (deflacionada pelo IPCA) de R $\$ 8,2$ bilhões, o que representou apenas 0,3\% do PIB e 1,8\% das receitas administradas pela Secretaria da Receita Federal nesse ano. Entretanto, apesar de sua natureza, a elevação das alíquotas do IOF foi usada em duas ocasiões, desde meados da década de 1990, para compensar a queda de arrecadação da CPMF. O fato de tanto a CPMF quanto o IOF ter nas operações financeiras seus fatores geradores contribuiu para essa estratégia do governo federal. Dessa maneira, a suspensão temporária da cobrança da CPMF no primeiro semestre de 1999 foi acompanhada pela elevação de alíquotas e da arrecadação do IOF, sendo que o mesmo movimento pôde ser verificado em 2008 com a não renovação da contribuição no final do ano anterior. Em 2010, a arrecadação do IOF (R \$23,9 bi- 
lhões) chegou então a 0,72\% do PIB e 4,7\% das receitas administradas pela Receita Federal (ver Tabela 1).

Tabela 1 - Receitas administradas pela Secretaria da Receita Federal e arrecadações do IOF e CPMF - em R \$ milhões (deflacionados pelo IPCA set./11=1)

\begin{tabular}{|c|c|c|c|c|c|}
\hline Ano & $\begin{array}{c}\text { IOF } \\
\text { arrecadação } \\
\text { (A) }\end{array}$ & $\begin{array}{c}\text { CPMF } \\
\text { arrecadação } \\
\text { (B) }\end{array}$ & $\begin{array}{c}\text { Receitas } \\
\text { Administradas } \\
\text { pela SRF (C) }\end{array}$ & $\mathrm{A} / \mathrm{C}$ & $\mathrm{B} / \mathrm{C}$ \\
\hline 1994 & $9.787,7$ & - & $186.608,0$ & $5,2 \%$ & \\
\hline 1995 & $7.897,1$ & - & $198.292,5$ & $4,0 \%$ & \\
\hline 1996 & $6.041,6$ & - & $194.131,1$ & $3,1 \%$ & \\
\hline 1997 & $7.491,4$ & $13.675,6$ & $212.020,2$ & $3,5 \%$ & $6,5 \%$ \\
\hline 1998 & $6.791,1$ & $15.570,5$ & $225.905,1$ & $3,0 \%$ & $6,9 \%$ \\
\hline 1999 & $8.921,1$ & $14.552,5$ & $260.039,7$ & $3,4 \%$ & $5,6 \%$ \\
\hline 2000 & $5.342,8$ & $24.853,4$ & $284.099,4$ & $1,9 \%$ & $8,7 \%$ \\
\hline 2001 & $5.733,9$ & $27.504,3$ & $301.955,3$ & $1,9 \%$ & $9,1 \%$ \\
\hline 2002 & $5.932,2$ & $30.037,0$ & $343.190,0$ & $1,7 \%$ & $8,8 \%$ \\
\hline 2003 & $5.722,0$ & $29.628,9$ & $329.356,7$ & $1,7 \%$ & $9,0 \%$ \\
\hline 2004 & $6.335,8$ & $31.878,3$ & $362.442,9$ & $1,7 \%$ & $8,8 \%$ \\
\hline 2005 & $6.883,1$ & $32.998,2$ & $389.835,3$ & $1,8 \%$ & $8,5 \%$ \\
\hline 2006 & $7.336,8$ & $34.681,2$ & $400.696,9$ & $1,8 \%$ & $8,7 \%$ \\
\hline 2007 & $8.237,5$ & $38.356,5$ & $453.386,7$ & $1,8 \%$ & $8,5 \%$ \\
\hline 2008 & $20.116,0$ & - & $474.428,2$ & $4,2 \%$ & \\
\hline 2009 & $18.143,9$ & - & $444.038,6$ & $4,1 \%$ & \\
\hline 2010 & $23.878,3$ & - & $504.205,9$ & $4,7 \%$ & \\
\hline
\end{tabular}

Fonte: Elaboração própria a partir de Brasil (2011b).

A arrecadação anual do IOF está condicionada pelas frequentes alterações de alíquotas, assim como pelas tendências verificadas nas diversas operações financeiras sobre as quais incidem, como o crescimento das operações de crédito, dos fluxos de capitais e das operações cambiais, que dependem da taxa de câmbio e do volume de negociações nos mercados financeiros. Entre essas operações financeiras, a maior contribuição à arrecadação resulta das operações de crédito, que, em 2010, foram responsáveis por $59 \%$ da receita, seguidas pelas operações de câmbio (25,3\% em 2010). As demais operações, juntas, representaram 15,6\% da arrecadação nesse ano (ver Gráfico 1). 
Gráfico 1 - Composição da arrecadação do IOF segundo o tipo de operação de incidência - 1995 a 2011 (em \%)

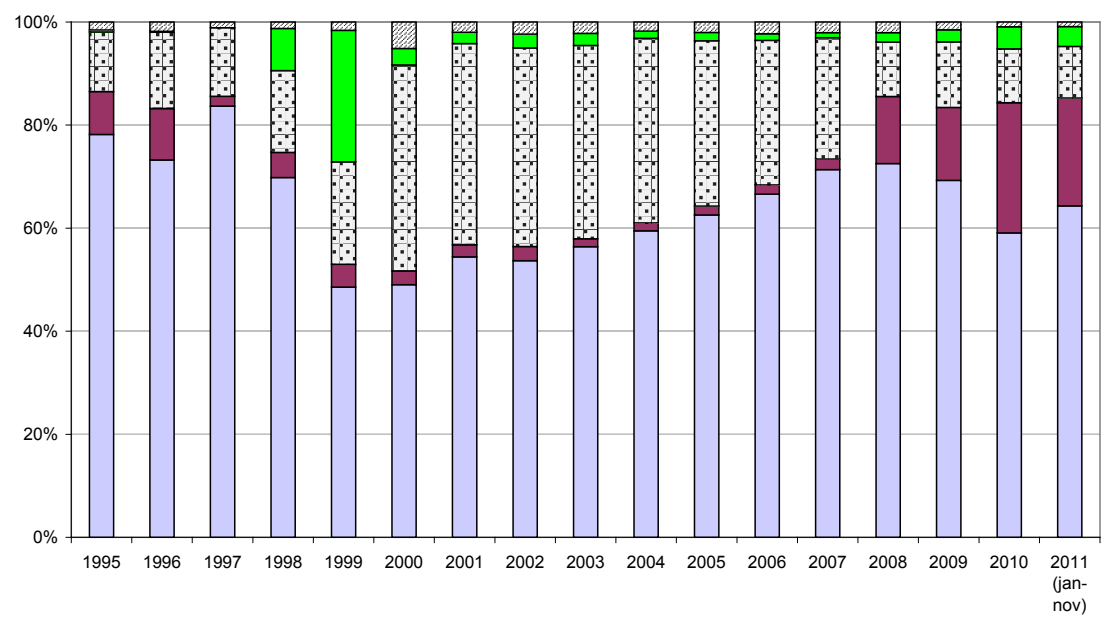

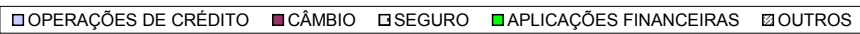

Fonte: Elaboração própria a partir de Brasil (2011c).

\subsection{A Busca por Fontes de Financiamento da Saúde e a Criação da CPMF}

A CPMF, por sua vez, foi criada com objetivo arrecadatório, de maneira a constituir uma base sólida para o financiamento do Ministério da Saúde. O processo de redemocratização do país na década de 1980, que culminou na Constituição de 1988, foi acompanhado da construção de um consenso a respeito da universalização do acesso à saúde no Brasil, sendo concretizado com a criação do Sistema Único de Saúde (SUS). Não se garantiu, em contrapartida, fontes de financiamento para o sistema. Além de recursos orçamentários das três esferas de governo, a Constituição previa apenas a vinculação da receita de contribuições de empregados e empregadores à Seguridade Social. Ao não vincular contribuições específicas aos ramos da Seguridade, como a saúde, a Constituição reforçava o caráter indivisível dos diferentes componentes da proteção social (previdência, saúde, assistência social). Na primeira metade dos anos 1990, ficaria clara a vulnerabilidade financeira à qual as ações do Ministério da Saúde estavam sujeitas, criando as condições políticas necessárias à instituição da CPMF em 1996 (MARQUES; MENDES, 2010).

Enquanto não se aprovava a Lei de Custeio da Seguridade Social, o artigo 55 do Ato das Disposições Transitórias estabeleceu que ao menos 30\% dos recursos do orçamento da Seguridade Social (excluído o seguro-desemprego) deveriam ser direcionados à saúde. Para os orçamentos de 1990 e 1991, foi definido por 
meio de negociação partidária que a saúde receberia os recursos provenientes do Fundo de Investimento Social (Finsocial), ${ }^{5}$ enquanto os programas assistenciais receberiam os recursos da Contribuição Social sobre o Lucro Líquido (CSLL). Nos anos subsequentes, com a aprovação da Lei de Custeio da Seguridade Social (Lei $n^{\circ} 8.212$ de 1991), que ratificou a não vinculação entre contribuições e políticas específicas, as fontes de financiamento da saúde passaram a ser definidas por meio de negociações políticas que se traduziam em uma vinculação informal das receitas. Dessa forma, em 1992, ficou definido que $25 \%$ do total das contribuições de empregados e empregadores seriam direcionados à saúde. Já no orçamento de 1993 essa parcela se reduziu para $15,5 \%$.

Em 1993, devido ao déficit da Previdência, os recursos que deveriam ser alocados à saúde foram retidos a partir do mês de maio. Dessa forma, foi a saúde que se tornou deficitária, obrigando o Ministério da Saúde a se endividar junto ao Fundo de Amparo ao Trabalhador (FAT). ${ }^{6}$ Frente à crise de financiamento da saúde, foi criado em julho de 1993 o Imposto Provisório sobre a Movimentação Financeira (IPMF), antecessor da CPMF, pela Emenda Constitucional $n^{\circ} 3$. Esse imposto vigorou apenas em $1994^{7}$ e foi extinto por ser considerado inconstitucional, uma vez que apenas as contribuições, e não os impostos, podem ser vinculadas a um tipo específico de gasto. Duas medidas do governo federal agravaram ainda mais a situação. Em primeiro lugar, antes mesmo de ter uma fonte de recursos garantida, o Ministério da Saúde, assim como o conjunto da Seguridade Social, ficou sujeito a um contingenciamento de recursos da ordem de $20 \%$ da arrecadação das contribuições sociais, que deveriam ser alocados no Fundo Social de Emergência (FSE). Criado em 1994, e renomeado Fundo de Estabilização Fiscal (FEF) em 1997, e de Desvinculação das Receitas da União (DRU) em 2000, esse fundo fazia parte do esforço de ampliação do superávit fiscal do governo federal. Em segundo lugar, o governo Fernando Henrique Cardoso deu início à negociação para a vinculação exclusiva das receitas com as contribuições de empregados e empregadores aos gastos da Previdência Social, que terminaria em 1998, com a aprovação no dia 19 de dezembro da Emenda Constitucional n ${ }^{\circ} 20$.

Nessas condições, ganharam força as pressões em defesa da resolução do problema de financiamento da saúde, o que viabilizou a reinstituição da antiga IPMF, agora sob a forma de uma contribuição, a CPMF, em outubro de 1996 (Lei

5 O Finsocial foi substituído em 1991 pela Contribuição para o Financiamento da Seguridade Social (Cofins), de acordo com a Lei Complementar $n^{\circ}$ 70, de 30 de dezembro de 1991.

6 O FAT é um fundo especial, de natureza contábil-financeira, vinculado ao Ministério do Trabalho e Emprego (MTE), destinado ao custeio do Programa do Seguro-Desemprego, do Abono Salarial e ao financiamento de Programas de Desenvolvimento Econômico.

7 A IPMF vigorou no mês de agosto de 1993, sendo suspenso durante os meses de setembro a dezembro desse ano pela Ação Direta de Inconstitucionalidade (Adin) n ${ }^{\circ}$ 939-7/DF, voltando a ser cobrado ao longo de todo o ano de 1994, para finalmente ser extinto. As arrecadações no ano de 1995 são apenas residuais sobre fatores geradores de 1994. 
$\mathrm{n}^{0}$ 9.311/1996). ${ }^{8} \mathrm{~A}$ alíquota que havia sido de $0,25 \%$ durante a vigência da IPMF, foi reduzida para $0,2 \%$ com a criação da CPMF, incidindo sobre "[...] qualquer operação liquidada ou lançamento realizado, pelas instituições financeiras, que representem circulação escritural ou física de moeda, e de que resulte ou não transferência da titularidade dos mesmos valores, créditos e direitos". O baixo patamar das alíquotas buscava impedir a corrosão da base de incidência do tributo - que ocorreria caso houvesse uma redução do número de transações financeiras em função de sua incidência -, garantindo uma arrecadação estável ao longo do tempo.

A história da CMPF foi, contudo, marcada pela constante crítica da opinião pública, especialmente dos setores ligados às instituições financeiras. Não raro, essa pressão contrária à CPMF se materializou em ações judiciais que tiveram impactos importantes sobre a arrecadação, como em 1999. Essas críticas encontravam ecos no exterior, especialmente nos organismos multilaterais, como o Fundo Monetário Internacional, e internamente no BCB. ${ }^{9}$

Um dos principais argumentos contrários à tributação de transações financeiras do tipo da CPMF identificava a possibilidade de impactos negativos sobre a intermediação financeira e sobre a competitividade das praças financeiras nacionais. Por estarem sujeitos a um custo adicional, referente à alíquota do tributo, os agentes econômicos buscariam, então, mecanismos de evasão fiscal que compreenderiam uma queda relativa do uso dos serviços bancários domésticos. No que se refere às bolsas de valores nacionais, a introdução do tributo corroeria uma parte da rentabilidade das operações, funcionando como um fator de estímulo à migração de investimentos das praças nacionais para as praças financeiras internacionais em que ativos semelhantes também fossem transacionados sem a incidência da tributação de transações financeiras (como, por exemplo, os American depositary receipts - $\mathrm{ADR}^{10}$ de empresas brasileiras negociadas na Bolsa de Valores de Nova York). Essas incitações à evasão fiscal estariam na origem da contração da base de arrecadação de tributos como a CPMF.

Diante das pressões dos mercados financeiros, foi criada em julho de 2004, pela Lei $\mathrm{n}^{\circ} 10.892$, a conta investimento, que viria, em boa medida, reduzir o custo de aplicação dos investidores financeiros. A conta investimento consistia em uma

8 A criação da CPMF não encerrou a questão do financiamento da saúde no Brasil, uma vez que seu caráter provisório implicava risco de não renovação e de perda da fonte de recursos, como de fato ocorreu em 2007. Para uma discussão sobre o financiamento da saúde no Brasil, ver Marques e Mendes (2010) e Servo et al. (2011).

9 Ver a esse respeito, Albuquerque (2001) e Koyama e Nakane (2001), que efetuam avaliações empíricas dos impactos da CPMF, sustentando argumentos contrários à sua cobrança. Vale ainda mencionar que esses estudos datam do início dos anos 2000 e não consideram, assim, a evolução positiva do crédito e dos mercados financeiros nacionais a partir de meados dessa década, quando ainda vigia a CPMF.

10 Os ADR consistem em certificados emitidos por bancos americanos representando ações de companhias estrangeiras. 
conta de depósito com o propósito exclusivo de realizar aplicações financeiras de renda fixa e variável de qualquer natureza. ${ }^{11}$ Por meio dessa conta, a realocação dos portfólios estaria isenta do pagamento de CPMF. Apenas as transferências entre a conta investimento e a conta corrente convencional continuaram sujeitas à contribuição. Em vigência a partir de $1^{\circ}$ de outubro de 2004, todas as novas aplicações financeiras (exceto em ações e em seus derivativos) tiveram de ser obrigatoriamente realizadas por meio das contas investimento. ${ }^{12}$ Com esse instrumento, buscava-se mitigar eventuais impactos negativos sobre a intermediação financeira (o custo de captação dos bancos seria reduzido, bem como o do governo e das empresas) e sobre a atratividade dos mercados de ações e títulos domésticos. Com a não prorrogação da CPMF em dezembro de 2007, a conta investimento foi extinta em maio de 2010 pelo $\mathrm{BCB}$ (Circular $\mathrm{n}^{\circ} 3.494$ ).

Apesar das recorrentes críticas dos setores contrários à CPMF (ver seção 3.2 deste artigo), a evolução dos estoques de crédito, sobretudo a partir de 2004, assim como dos volumes negociados na principal bolsa de valores do país (BMEFFBovespa) sugerem, de fato, que a existência da CPMF não constituiu um entrave às intermediações bancária e financeira. Ademais, como apontam Coelho et al. (2001) e os dados da Receita Federal (ver Tabela 1), a arrecadação da CPMF se manteve em trajetória ascendente desde sua criação, contestando, assim, seu impacto negativo sobre sua base de incidência. Entre os anos de 1997 e 2007, quando o volume de recursos arrecadados (deflacionados pelo IPCA) saltou de $\mathrm{R} \$$ 13,7 bilhões ( $0,7 \%$ do PIB) para $\mathrm{R} \$ 38,3$ bilhões (1,4\% do PIB), a CPMF representou, em média, $8,1 \%$ das receitas administradas pela Secretaria da Receita Federal.

Ainda que o principal argumento em defesa da instituição da CPMF em 1996 tivesse sido a necessidade de financiamento do Ministério da Saúde, os recursos arrecadados pela contribuição nunca foram integralmente direcionados à saúde (ver Tabela 2). Além da incorporação de novos objetivos - como complementar as fontes de financiamento da previdência social (1999) e integrar o fundo de combate à pobreza (2000) -, que foi acompanhado de elevação das alíquotas (ver Quadro 2 no Apêndice A), o Ministério da Saúde esteve sujeito ao contingenciamento dos recursos arrecadados pela CPMF desde o princípio, com a criação do Fundo Social de Emergência (FSE/FSF), e posteriormente da DRU, na ordem de $20 \%$ dos recursos arrecadados.

11 As contas investimento podiam ser individuais ou conjuntas, não podendo ser movimentadas por meio de cheques e não deviam remunerar seus eventuais saldos positivos (não aplicados).

12 Em regra geral, não integravam a conta investimento as operações com ações e seus derivativos, realizadas em bolsa de valores ou no mercado balcão, e as operações de liquidação futura quando sujeitas a ajustes diários. 
Tabela 2 - Destino dos recursos arrecadados pela CPMF (em \%) - de 1997 a 2007

\begin{tabular}{l|r|r|r|r|r}
\hline $\mathbf{A n o}$ & $\begin{array}{c}\text { Arrecadação } \\
\text { (R\$ mil- } \\
\text { hões, valor } \\
\text { corrente) }\end{array}$ & Saúde & $\begin{array}{c}\text { Previdência } \\
\text { social }\end{array}$ & $\begin{array}{c}\text { Fundo de } \\
\text { combate e } \\
\text { erradicação } \\
\text { da pobreza }\end{array}$ & $\begin{array}{r}\text { Saldo no } \\
\text { caixa do } \\
\text { Tesouro* }\end{array}$ \\
\hline $\mathbf{1 9 9 7}$ & $6.909,4$ & $74,9 \%$ & $0,0 \%$ & $0,0 \%$ & $25,1 \%$ \\
$\mathbf{1 9 9 8}$ & $8.118,1$ & $80,0 \%$ & $0,0 \%$ & $0,0 \%$ & $20,0 \%$ \\
$\mathbf{1 9 9 9}$ & $7.955,9$ & $53,8 \%$ & $43,3 \%$ & $0,0 \%$ & $3,0 \%$ \\
$\mathbf{2 0 0 0}$ & $14.544,6$ & $47,3 \%$ & $33,5 \%$ & $0,0 \%$ & $19,2 \%$ \\
$\mathbf{2 0 0 1}$ & $17.197,0$ & $41,5 \%$ & $21,3 \%$ & $21,1 \%$ & $16,2 \%$ \\
$\mathbf{2 0 0 2}$ & $20.367,6$ & $50,1 \%$ & $13,1 \%$ & $21,1 \%$ & $15,8 \%$ \\
$\mathbf{2 0 0 3}$ & $23.047,2$ & $40,8 \%$ & $21,2 \%$ & $21,1 \%$ & $17,0 \%$ \\
$\mathbf{2 0 0 4}$ & $26.432,8$ & $39,5 \%$ & $20,1 \%$ & $21,1 \%$ & $19,4 \%$ \\
$\mathbf{2 0 0 5}$ & $29.241,1$ & $36,9 \%$ & $20,3 \%$ & $21,1 \%$ & $21,8 \%$ \\
$\mathbf{2 0 0 6}$ & $32.018,1$ & $40,2 \%$ & $21,1 \%$ & $21,1 \%$ & $17,7 \%$ \\
$\mathbf{2 0 0 7}$ & $36.700,7$ & $41,5 \%$ & $20,6 \%$ & $21,1 \%$ & $16,8 \%$ \\
\hline
\end{tabular}

Fonte: Elaboração própria a partir de dados de HICKMANN; SALVADOR,(2007) BRASIL (2008) e BRASIL (2011d).

Nota: * Recursos desvinculados por meio do FEF ou da DRU e que não retornaram para as políticas de saúde, previdência social ou não foram destinados ao Fundo de Combate e Erradicação da Pobreza. Inclui também recursos autorizados no orçamento, mas não executados.

\section{Papéis Adicionais dos Tributos sobre as Transações Financeiras no Brasil}

A experiência brasileira com a tributação de transações financeiras é bastante ilustrativa dos múltiplos usos que esse tipo de imposto pode assumir, seja em termos de ampliação da capacidade de intervenção governamental em mercados inerentemente instáveis, ${ }^{13}$ como é o caso do mercado financeiro, seja em termos do aumento da arrecadação associada ao fechamento de brechas para evasão fiscal. No caso específico do IOF, as alterações das alíquotas e/ou ampliação da base de incidência, ao incluir as transações com derivativos, constituíram um importante instrumento auxiliar tanto na gestão dos fluxos de capitais e das transações cambiais com propósito de política econômica, quanto na inibição de comportamentos de risco por parte dos agentes privados nos mercados de crédito e de câmbio. Já a CPMF se revelou uma ferramenta eficaz de combate à sonegação fiscal

13 Ultrapassa largamente os objetivos deste artigo discutir as diferentes abordagens teóricas sobre a natureza e o funcionamento dos mercados na economia capitalista contemporânea. Cabe explicitar, contudo, que os autores compartilham a interpretação de Hyman Minsky (1986). 


\subsection{O IOF como Instrumento de Controle e Gestão dos Fluxos de Capitais, Regulação Macroprudencial e Política Financeira}

Como já mencionado, desde sua origem, enquanto imposto regulatório, o IOF tem sido instrumento auxiliar das políticas monetária e cambial. Contudo, desde o final da década de 2000 , esse imposto passou a ser utilizado pelas autoridades econômicas brasileiras também com o duplo propósito de regulação macroprudencial ${ }^{14} \mathrm{e}$ de controle dos fluxos de capitais. ${ }^{15}$ Esse novo papel do IOF emergiu em um contexto de forte ampliação dos fluxos de investimento estrangeiro de portfólio $(\mathrm{IEP})^{16}$ associado à liquidez internacional abundante direcionada aos países emergentes a partir de 2003. No Brasil, esse movimento, que teve início em 2005, ganhou ímpeto em 2007. Interrompido pela eclosão da crise internacional em setembro de 2008, o afluxo de investimentos estrangeiros foi retomado ainda em 2009.

O montante de recursos investidos pelos estrangeiros no mercado de capitais, e, em particular, no mercado acionário doméstico, saltou de US $\$ 28,6$ bilhões, em janeiro de 2005 (US $\$ 20$ bilhões em 2003), para US\$104,4 bilhões, em janeiro de 2007, alcançando um patamar recorde de US $\$ 264$ bilhões em maio de 2008. ${ }^{17}$

14 Como regulação de natureza macroprudencial entendem-se aquelas medidas cujo efeito direto sobre as operações ativas e passivas das instituições bancárias ajudaria a evitar riscos potenciais de instabilidade financeira associada ao comportamento pró-cíclico do sistema bancário. Instrumentos das diversas políticas macroeconômicas (monetária, fiscal, cambial) podem ser utilizados com a finalidade de limitar a assunção excessiva de risco que possa resultar em problemas de iliquidez e/ou insolvência de uma ou mais instituições financeiras, resultando, assim, na iliquidez dos mercados, na venda forçada de ativos, na deterioração dos balanços e na contração abrupta do crédito. Do mesmo modo, medidas macroprudenciais podem ser instrumentos auxiliares na busca dos objetivos das demais políticas. Por exemplo, o aumento da tributação das operações de crédito para evitar o risco sistêmico no mercado de crédito pode auxiliar tanto no combate à inflação - uma vez que o controle sobre a oferta de crédito afeta o consumo e desacelera a atividade econômica, potencializando os efeitos da política de juros -, quanto na elevação da arrecadação, contribuindo para ampliação da folga fiscal (MORENO, 2011).

15 Enquanto a política cambial se refere à gestão do regime cambial em vigor e à intervenção efetuada para alcançar seus objetivos e metas (acúmulo de reservas internacionais, atenuação da volatilidade cambial e a influência sobre o patamar da taxa de câmbio), a gestão dos fluxos de capitais diz respeito à administração dos graus de liberdade das transações cambiais realizadas pelos agentes privados e inclui mecanismo de controles de capital no sentido estrito e mecanismos de regulamentação financeira prudencial. Como ressalta Prates (2007), a gestão dos fluxos de capitais contribui para ampliar a margem de manobra da política cambial.

16 Os investimentos estrangeiros de portfólio (IPE) referem-se aos fluxos de capital para compra de ativos mobiliários (ações no limite de 10\% do capital da empresa, títulos de renda fixa, cotas de fundos mútuos de investimento) por investidores não residentes.

17 A participação dos investidores estrangeiros no volume de negócios no mercado acionário alcançou o patamar recorde de 36,2\% em 2008 (antes 22,3\%, em 2002, e 27,0\% em 2004). Após o recuo para 31,6\%, em 2009, a participação estrangeira na BMËFBovespa voltou a subir com o retorno dos fluxos de capital, atingindo 34,7\% em dezembro de 2011. 
A contrapartida da entrada de um volume de recursos de tal magnitude foi a acumulação de reservas internacionais e a apreciação do real, com reflexos deletérios sobre a competitividade das exportações brasileiras.

Desde a adoção do regime de câmbio flutuante, em 1999, até março de 2008, as autoridades econômicas brasileiras efetuaram poucas intervenções ativas para conter seja a volatilidade cambial, seja a apreciação do real frente ao dólar, em razão dos seus efeitos benéficos para a estabilidade dos preços. ${ }^{18}$ Prevalecia no governo, bem como na academia e nos organismos internacionais, a visão de que medidas de controle dos fluxos de capital afetavam negativamente o desempenho macroeconômico e comprometia o crescimento. ${ }^{19}$ As intervenções do $\mathrm{BCB}$ no mercado de câmbio se limitavam aos propósitos de impedir que a volatilidade cambial excessiva afetasse as expectativas dos agentes e de reduzir a vulnerabilidade externa, mediante o acúmulo de reservas, sem, contudo, se comprometer com um patamar determinado para a taxa de câmbio que garantisse a manutenção da competitividade da economia brasileira. ${ }^{20}$

Porém, frente os afluxos recordes de IEP, em 2007 e nos meses iniciais de 2008, que conduziram a uma forte apreciação da moeda brasileira em relação ao dólar (mais de 12\% entre início de junho de 2007 e fevereiro de 2008) (ver Gráfico 2), o governo brasileiro voltou a utilizar o IOF como instrumento auxiliar da política cambial e, mais especificamente, como uma modalidade de controle de capitais. Assim, em março de 2008, com intuito de conter a apreciação do real e reduzir a volatilidade cambial pela contenção dos fluxos de capitais especulativos, a alíquota de IOF sobre os investimentos de portfólio de renda fixa foi elevada a 1,5\% (Decreto ${ }^{\circ}$ 6.391, de 12 de março de 2008). Tal medida, contudo, se revelou insuficiente, pois, além do seu alcance estar limitado a transações efetuadas no mercado à vista de câmbio, não foi acompanhada por intervenções ativas da autoridade monetária nesse mercado nem por qualquer medida de controle de capital do tipo quantitativo (ou administrativo).

18 Em razão dos efeitos da taxa de câmbio na formação dos preços domésticos e na formação das expectativas dos agentes, a apreciação cambial revelou-se o principal mecanismo de transmissão da política de metas de inflação no Brasil, propiciando a desaceleração dos índices de preço e reforçando, assim, a própria eficácia dessa política. Sobre esse ponto, ver, entre outros, Modenesi (2005), Farhi (2007) e Freitas (2010).

19 A discussão teórica e/ou empírica sobre os prós e contras da adoção de controles de capitais, bem como a avaliação da política cambial brasileira ultrapassam os propósitos desse texto. Sobre esses pontos, ver Carvalho e Sicsú (2006), Paula, Oreiro e Silva (2003), Prates (2006), Silva e Rezende (2010) e Ostroy et al. (2010).

20 Sobre as intervenções do BCB no mercado de câmbio, ver Prates (2010). 
Gráfico 2 - Evolução da taxa de câmbio nominal* e das alíquotas de IOF sobre fluxos de capitais e sobre transações cambiais

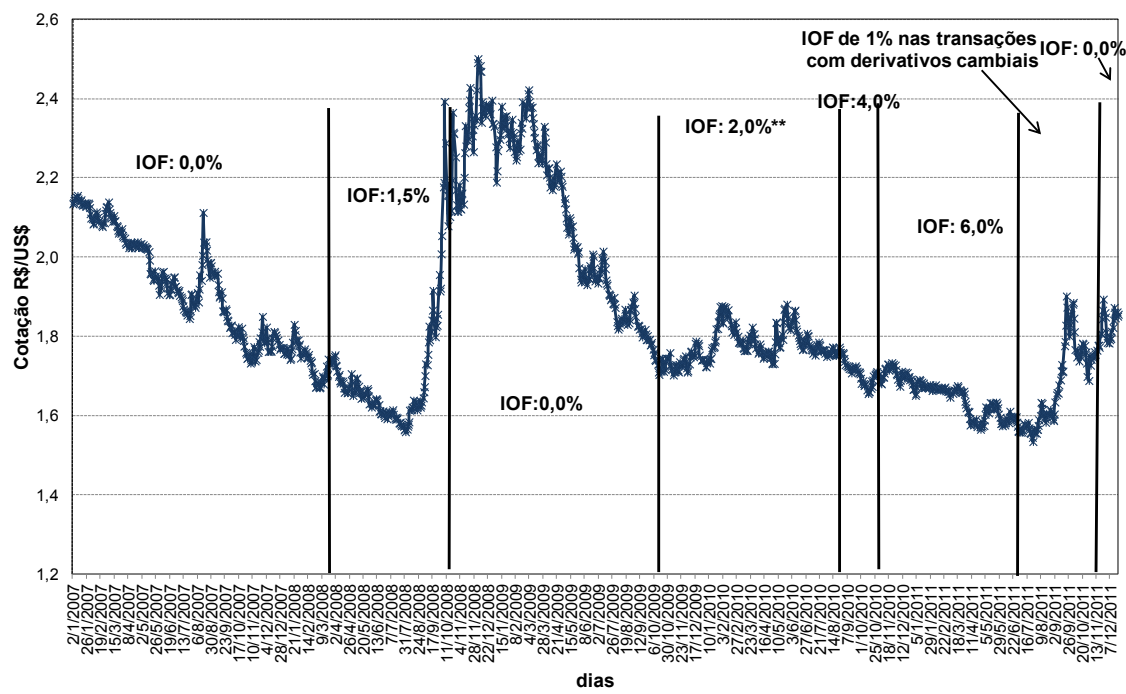

Fonte: Elaboração própria a partir de BRASIL (2011e).

Nota: * Taxa spot diária;"* em novembro de 2009, o IOF de 1,5\% passou a incidir sobre transações com ADR, para evitar que os investidores cancelassem suas ordens de compra e reaplicassem os recursos em títulos de renda fixa.

A eclosão da crise financeira global em setembro de 2008 teve fortes impactos sobre a economia brasileira tanto pela via do comércio quanto pela via dos fluxos de capitais. O expressivo aumento da aversão aos riscos desencadeou um movimento generalizado de fuga para a qualidade dos investidores globais, com consequente saída de capitais e virtual interrupção das linhas externas de crédito comercial (ver Gráfico 3), resultando, assim, na abrupta desvalorização do real. Como entre 15 de setembro e 15 de outubro o real se depreciou em $22,7 \%$, o governo reduziu a zero a alíquota do IOF sobre as aplicações dos investidores estrangeiros (Decreto $n^{\circ}$ 6.983, de 19 de setembro de 2009; Decreto $n^{\circ} 6.984$, de 20 de outubro de 2009), entre outras medidas de mitigação do impacto da crise sobre o mercado de crédito e o nível de atividade (PRATES, 2010, 2009). 


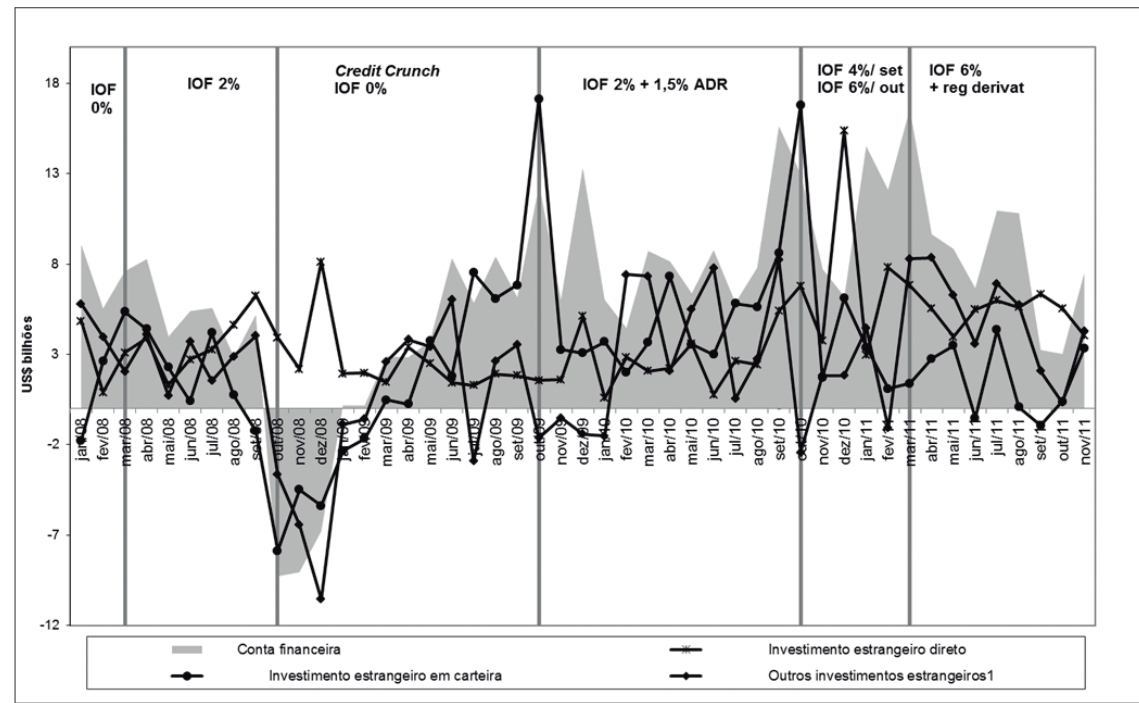

Fonte: Elaboração própria a partir de BRASIL (2011e)

Nota: ${ }^{1}$ Inclui crédito comercial e empréstimos e financiamentos de curto e longo prazo.

Com o retorno dos fluxos de capitais privados a partir de meados de 2009 - atraídos pela ampliação do diferencial entre os juros internos, mantidos em patamar ainda bastante elevado, e os juros externos próximos de zero, e pelas perspectivas de maior dinamismo da economia brasileira, em um cenário de lenta recuperação das economias centrais -, o real retomou a sua trajetória de apreciação. A crescente deterioração da competitividade externa da indústria brasileira levou o governo a utilizar, ainda que de modo gradual, o IOF como instrumento de controle de capitais, stricto sensu, ou seja, controle do mercado baseado em preços, para conter a excessiva apreciação do real. ${ }^{21}$ Entre outubro de 2009 e julho de 2011, as autoridades econômicas elevaram diversas vezes as alíquotas de IOF sobre investimentos estrangeiros de portfólio e sobre as captações externas de empresas e bancos brasileiros, ampliando o campo de incidência para fechar as brechas utilizadas pelos agentes para contornar o aumento do imposto. Tais foram, entre outros, os casos da tributação das operações envolvendo ADR e das captações externas com prazos acima de 720 dias com liquidação antecipada.

21 Diferentemente do que ocorreu no passado, embora tenha desagradado aos participantes do mercado financeiro, avessos por princípio a toda e qualquer intervenção estatal que reduza seus lucros, essa decisão do governo brasileiro de impor controle sobre os fluxos de capitais foi bem recebida pelos organismos internacionais. A crise global de 2008-2009, ao explicitar as fragilidades financeiras associadas aos vultosos e voláteis fluxos internacionais de capital, levou o próprio FMI, crítico acerbo dos controles de capital, a admitir sua utilização com propósito de assegurar a estabilidade financeira. Sobre esse ponto, ver Ostroy et al. (2010) e Forbes, et al. (2011). 
Em 2011, o IOF passou, igualmente, a ser utilizado como um instrumento de regulação macroprudencial, com o objetivo de garantir a estabilidade financeira. De forma complementar à ação do BCB que, em dezembro de 2010, havia identificado o potencial de risco sistêmico no mercado de crédito, a alíquota do IOF sobre diversas modalidades de crédito ao consumo foi elevada de 1,5\% para 3\% em abril de 2011 (Decreto $n^{\circ} 7.458$, de 7 de abril de 2011). Naquela ocasião, para conter o crescimento acelerado do crédito ao consumo - que foi acompanhado de alongamento de prazos e poderia implicar em endividamento excessivo das famílias e em descasamento de prazo nas operações bancárias - a autoridade monetária elevou os requerimentos de capital e de depósito compulsório das instituições bancárias. ${ }^{22}$ Em março, para conter os riscos de descasamento de moeda associados ao aumento dos gastos de brasileiros no exterior, bem como compensar a perda de arrecadação em razão do reajuste da tabela do imposto de renda recolhido na fonte, o IOF sobre gastos com cartão de crédito no exterior também já havia sido elevado para 6,38\% (Decreto no 7.454 de 25 de março de 2011) (FUNDAP, 2011).

A imposição de IOF de 1\% (alíquota que pode ser elevada, se necessário, até $25 \%$, segundo o Decreto $n^{\circ} 7.536$ de 26 de julho de 2011 ) sobre as posições líquidas vendidas em derivativos cambiais acima de US $\$ 10$ milhões se enquadra igualmente como uma medida de natureza macroprudencial. Além de desestimular as operações especulativas com derivativos cambiais (ver Apêndice B), que estiveram na origem da fragilidade financeira de empresas e bancos em 2008, o IOF sobre os derivativos ajuda a reduzir a volatilidade sobre o câmbio e potencializa os efeitos das medidas de gestão dos fluxos de capitais previamente adotadas, inclusive a instituição pelo $\mathrm{BCB}$, em 6 de janeiro de 2011, de um depósito compulsório (em reais) de $60 \%$ do valor das posições vendidas em câmbio e assumidas pelos bancos (Circular $\left.n^{\circ} 3.520\right)$.

Recentemente, o IOF também voltou a ser utilizado pelo governo federal como instrumento de política financeira para estímulo à construção de um mercado secundário de títulos privados de renda fixa. No âmbito do amplo pacote de medidas de estímulo ao financiamento privado de longo prazo lançado em dezembro de $2010,{ }^{23}$ a tributação do mercado de capitais foi alterada para atrair investidores. Por meio do Decreto $n^{\circ} 7.412$, de 30 de dezembro de 2010, o governo, além de eliminar a cobrança de IOF nas operações de compra e venda de títulos privados com prazo de até 30 dias, modificou a tributação sobre rendimentos pe-

22 As medidas de natureza macroprudenciais no mercado do crédito tinham igualmente a finalidade de conter o consumo das famílias, alavancado pelo crédito bancário, que registravam taxas reais de crescimento da ordem de dois dígitos, e assim mitigar as pressões inflacionárias crescentes em um contexto de forte elevação nos preços internacionais das commodities (FUNDAP, 2011). da por Freitas (2011). 
riódicos ("cupom de remuneração") pagos aos investidores, estabelecendo que a negociação de títulos fora da data de pagamento do cupom não gerará tributação adicional. Igualmente, foi concedida, a partir de janeiro de 2011, desoneração do IOF incidente sobre a entrada de recursos estrangeiros em fundos de private equity, tais como os fundos de investimento em participação (FIP) e os fundos mútuos de investimentos em empresas emergentes (FMIEE). Em dezembro de 2011, foi zerada a alíquota sobre as operações de câmbio associadas a esses investimentos, bem como as aplicações de não residentes em títulos privados com prazo superior a seis anos (duration de quatro anos) vinculados a projetos de investimento em infraestrutura.

\subsection{A CPMF e o Combate à Sonegação Fiscal}

Depois de 2001, com a promulgação da Lei no 10.174, que autorizou o cruzamento da informação da movimentação financeira com a declaração de renda, a CPMF passou a desempenhar com eficiência um duplo papel, ao servir como instrumento arrecadatório e mecanismo de combate à sonegação fiscal. Entretanto, seu êxito como instrumento de fiscalização contribuiu, sem dúvida, para a sua extinção, ainda que os argumentos "técnicos" levantados pelos seus críticos tenham respaldado essa decisão. Diferentemente das conclusões negativas dos estudos econométricos de inspiração neoclássica, realizados por economistas tanto de organismos multilaterais quanto do $\mathrm{BCB}$, a experiência brasileira com esse tipo específico de tributo sobre as transações tributárias foi bastante exitosa. ${ }^{24} \mathrm{~A}$ arrecadação da CPMF subiu ao longo do tempo (ver Tabela 2), resultado que refuta a objeção teórica de que esse tipo de tributo sobre as transações financeiras acarretaria a corrosão da sua própria base de incidência ao desencadear desintermediação bancária.

A hipótese da sofisticação do sistema financeiro brasileiro, levantada por Coelho et al. (2001), constitui apenas uma parte da explicação para o fato de não ter ocorrido no Brasil um processo de desintermediação em decorrência da CPMF. De fato, em razão da prolongada convivência com elevadas e crescentes taxas de inflação, os bancos brasileiros desenvolveram notória expertise na gestão dos fluxos de pagamentos que transitam pelo sistema financeiro nacional, reconhecida pelos clientes, bem como por seus concorrentes estrangeiros. Porém, importantes mudanças estruturais ocorridas na economia brasileira durante a vigência da CPMF, sobretudo a partir de 2003, contribuíram para ampliação da intermediação (expressa na forte expansão do crédito bancário e no crescimento do número de

24 A contribuição da arrecadação da CPMF no financiamento do Ministério da Saúde entre 1997 e 2007 foi, em média, 31\% (ver Tabela 3, no Apêndice). 
contas correntes e de poupança), bem como para o aumento das transações no mercado de capital, em particular no mercado acionário.

A combinação de um cenário externo favorável - caracterizado por elevadas taxas de crescimento da economia mundial, baixas taxas de inflação, liquidez internacional abundante, expansão do volume de comércio mundial e ganhos de termos de troca das economias produtoras de commodities - com a adoção de políticas governamentais ativas de distribuição de renda e inclusão social, no âmbito doméstico, favoreceram o surgimento de expectativas positivas por parte dos agentes econômicos. Nesse contexto, que resultou em maior dinamismo da economia brasileira e, consequentemente, do mercado de trabalho, com aumento da formalização do emprego, criou-se um círculo virtuoso no qual o consumo lastreado na expansão do crédito e da renda gerou demanda para os setores terciários e para a indústria de transformação.

De um lado, as expectativas favoráveis de evolução do emprego e da renda levaram os bancos a priorizar a concessão de crédito às pessoas físicas, estimulando o endividamento das famílias mediante o alongamento dos prazos dos financiamentos para a aquisição de bens duráveis, em particular para a aquisição de veículos. ${ }^{25}$ De outro lado, a política de aumento real do salário mínimo, aliada às políticas sociais distributivas de renda (cujo destaque é o programa Bolsa Família), beneficiou o mercado doméstico, a empregabilidade e a renda familiar dos estratos mais pobres da população e estimulou a ampliação do mercado interno, com inclusão de novos consumidores, inclusive de bens duráveis, dependentes da ampliação do crédito (FREITAS, 2007).

A introdução do crédito consignado ${ }^{26}$ no final de 2003 e o crescimento da massa de rendimentos a partir de 2004 impulsionam ainda mais a expansão dos empréstimos ao consumo. Esse movimento foi alimentado pelo avanço da "bancarização" da população brasileira. Como o acesso ao sistema bancário depende da comprovação de vínculos econômicos formais tanto pelo empresário quanto pelo trabalhador, as sinergias do mercado de trabalho - queda da taxa de desocupação e aumento da massa de rendimento e do emprego formal - realimentaram a fase expansiva do ciclo de crédito e deram sustentação ao consumo (FREITAS; PRATES, 2009).

Assim, entre 2003 e o final de 2007, período em que vigorou a alíquota mais elevada da CPMF (0,38\%), ocorreu no Brasil uma forte e rápida ampliação do crédito bancário ao setor privado, que saltou do patamar de 21,3\% do PIB, em dezembro de 2002, para 33\% do PIB, em dezembro de 2007 (ver Gráfico 4). Mes-

25 Para mais detalhes sobre os determinantes e as características da expansão recente do crédito, ver Cintra (2006) e Freitas (2007).

26 O crédito consignado, com desconto em folha de pagamento, para trabalhadores ativos e inativos, foi instituído pela Lei $\mathrm{n}^{\circ} 10.820$, de 17 de dezembro de 2003, com o intuito de favorecer a redução do custo dos empréstimos. 
mo a introdução do adicional de 0,38\% do IOF sobre as operações de crédito, em janeiro de 2008, como medida compensatória da perda de arrecadação associada à extinção da CPMF não interrompeu esse processo.

Gráfico 4 - CPMF e evolução do crédito total ao setor privado como porcentagem do PIB* (de janeiro de 1996 a janeiro de 2010)

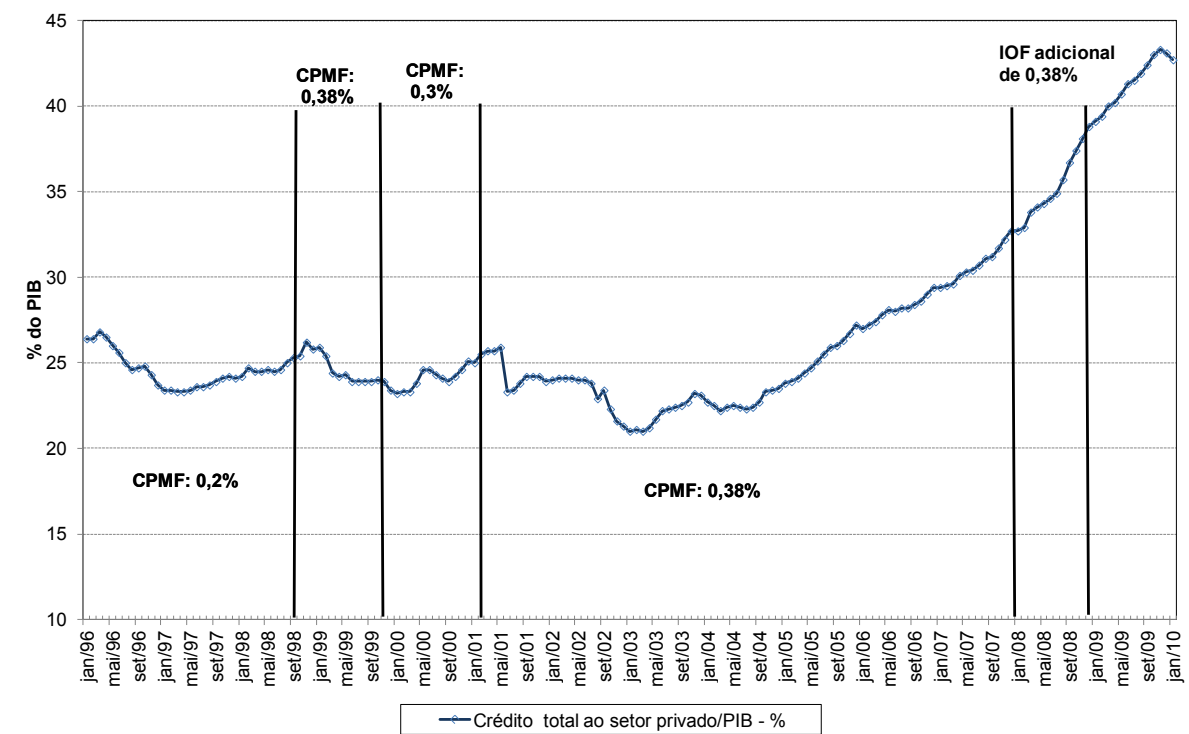

Fonte: Elaboração própria a partir de BRASIL (2011e).

Nota: "Dados deflacionados pelo IGP-DI centrado. Essa série (11399) foi descontinuada pelo BCB em 2010. O último dado disponível refere-se a janeiro de 2010. A nova série de crédito como porcentagem do PIB em valores correntes inicia-se em janeiro de 2001.

Nesse mesmo período, o número de contas bancárias saltou de 77,3 milhões, em 2002, para 112,1 milhões, em 2007, o que representa um crescimento da ordem de $45 \%$ (ver Gráfico 5). Uma evolução semelhante ocorreu com o número de clientes com conta de poupança, que registrou alta de $41,1 \%$ na mesma base de comparação, alcançando 82,1 milhões no final de 2007 (58,2 milhões em 2002). Tais aumentos refletiram o crescimento tanto da formalização das relações de trabalho, quanto da ocupação e da renda e da política de inclusão social, que implicou a inclusão financeira dos estratos mais pobres da população, mediante a criação de contas bancárias populares junto aos bancos públicos federais. ${ }^{27}$

27 Esse foi o caso da Caixa Econômica Federal (CEF), que, seguindo orientação do governo federal, lançou em 2003 a conta Caixa Aqui, que permitiu a abertura de conta corrente simplificada para uma parcela da população até então excluída do sistema bancário. 
Gráfico 5 - Evolução do número de contas correntes e no número de clientes com conta de poupança, em milhões

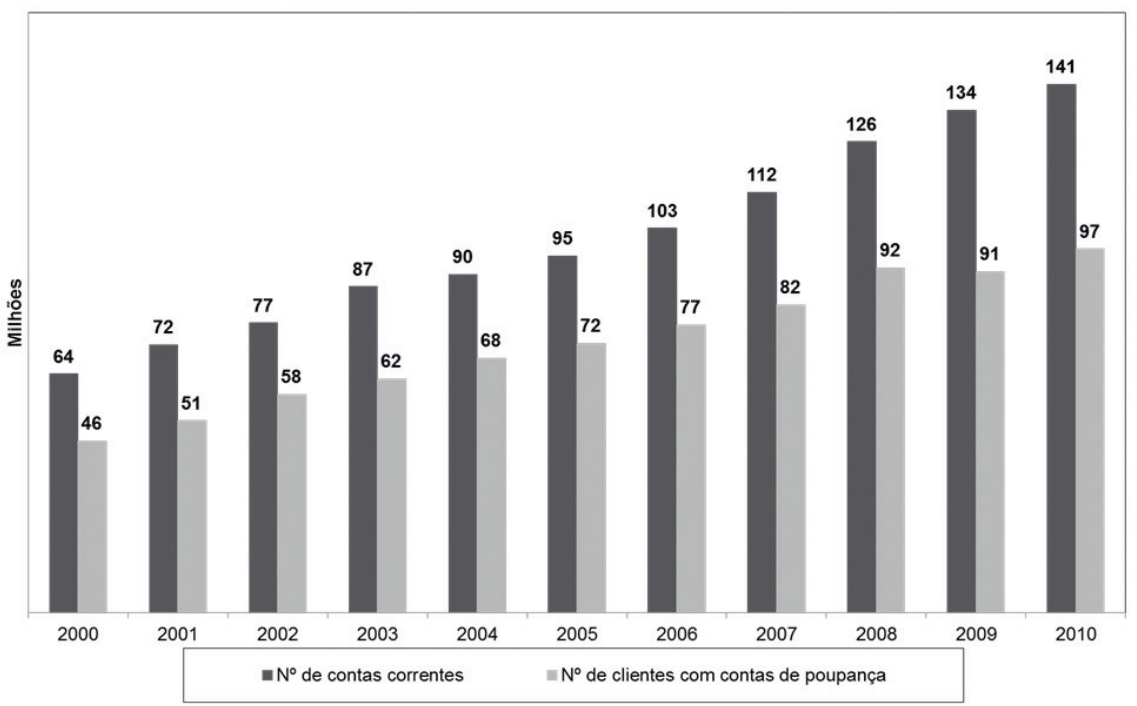

Fonte: Elaboração própria a partir de Federação Brasileira de Bancos (2011).

Tal como observado no caso da intermediação bancário e do crédito, a CPMF não constituiu um obstáculo para a forte expansão do mercado acionário brasileiro, impulsionada por fatores externos (retorno dos investimentos estrangeiros de portfólio a partir de 2003 e ampliação crescente desses investimentos a partir de 2005) e pelo maior dinamismo da economia brasileira, associado não apenas ao crescimento dos setores exportadores, mas também dos setores voltados para o mercado interno, em um cenário de consolidação da estabilidade monetária. ${ }^{28}$ Entre 2002 e 2007, o indicador de negócios da BMEFBovespa, o Ibovespa, subiu em termos nominais de 11 mil pontos para 64 mil pontos (ver Gráfico 6), o que representa uma variação nominal da ordem de $467 \%$. Em dólar, a ampliação das transações no mercado acionário secundário foi ainda mais extraordinária: $1.031 \%$, saltando de 3 mil para 36 mil pontos no mesmo período. Essa expressiva valorização do mercado acionário doméstico, alavancada pela ampliação da presença de investidores estrangeiros, estimulou a abertura de capital de empresas brasileiras mediante ofertas públicas iniciais (IPO, na sigla em inglês), bem como emissões de ações por empresas já listadas em bolsa (emissões subsequentes). O número total de emissões de ações subiu de apenas 4, em 2002, para o recorde de 76 emissões, em 2007, representando um volume total de recursos da ordem de

28 Sobre os determinantes externos e internos da expansão do mercado doméstico de capitais, ver Biancareli (2007) e Freitas (2009). 
$\mathrm{R} \$$ 69,5 bilhões. Já o número de IPO saltou de 7, em 2004, para 64 em 2007. De acordo com Freitas (2009), nesse período o volume captado nos IPO saltou de R\$ 4,4 bilhões, em 2004, para $R$ \$ 55,8 bilhões, em 2007, com participação crescente dos investidores estrangeiros na aquisição das emissões das novas entrantes: de 82\%, em 2007, contra 70\%, em 2004.

Gráfico 6 - CPMF e evolução dos negócios na bolsa de valores (Ibovespa)

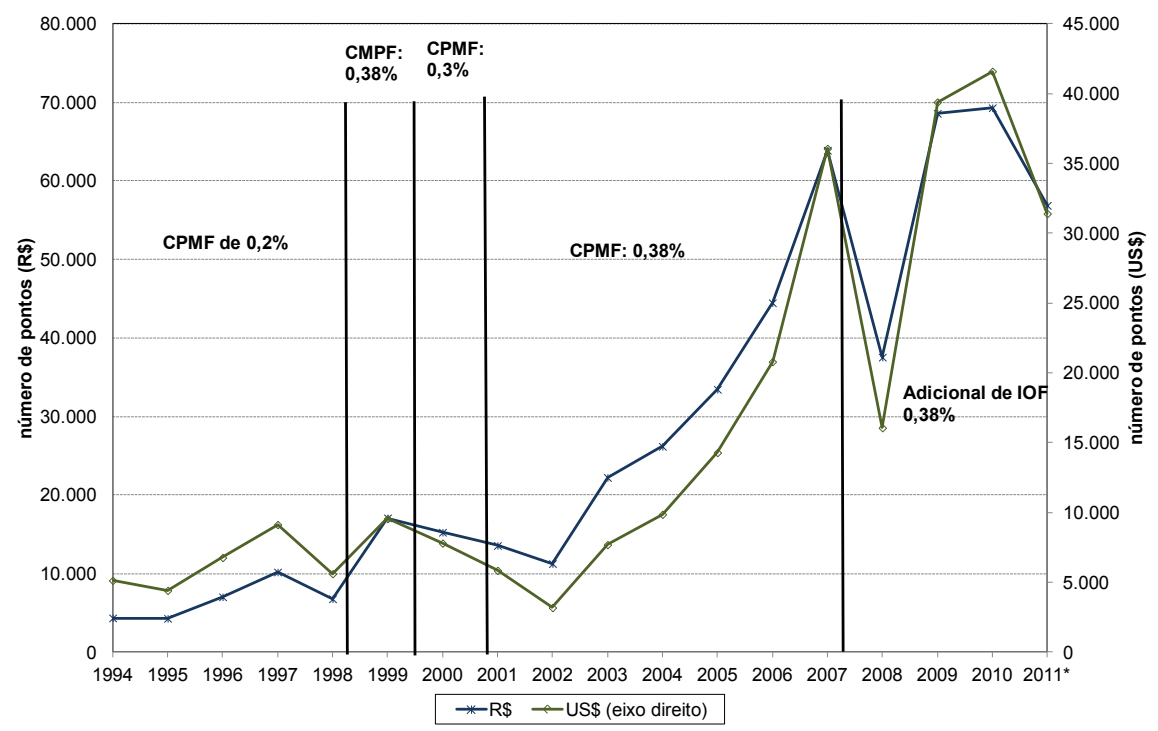

Fonte: Elaboração própria a partir de Bolsa de Mercadorias, Futuros e Valores (2011).

Nota: "Ibovespa em 2011 refere-se à posição até novembro.

Além de reforçar as poucas evidências de impactos relevantes da cobrança da CPMF sobre a alocação de recursos na economia, aspectos de ordem administrativa geralmente são enfatizados por técnicos da Receita Federal, sobretudo, a simplicidade do cálculo do tributo a ser pago e a facilidade de arrecadação, que utiliza o próprio sistema bancário. Com a Lei n ${ }^{\circ} 10.174$ de 2001, a CPMF assumiu um novo papel, passando a funcionar como instrumento importante no combate à sonegação fiscal e à "lavagem de dinheiro". A partir de então, o governo foi autorizado a cruzar as informações sobre o rendimento dos contribuintes, pessoas físicas ou jurídicas, obtidas nas declarações de imposto de renda com os pagamentos da CPMF. Até então, a Lei no 9.311 de 1996 proibia esse tipo de prática.

Ainda que os dados detalhados não sejam disponibilizados pela Receita Federal, Viol et al. (2001) ilustram a importância da comparação dos pagamentos da CPMF e do imposto de renda com dados de 1998, apurados junto aos 50 maiores bancos do país. O número total de pessoas físicas com movimentação bancária 
que pagaram CPMF nesse ano foi de 38,5 milhões, mas apenas 9,9 milhões declararam o imposto de renda. O número de isentos chegou a 17 milhões de pessoas, que haviam movimentado $\mathrm{R} \$ 192,3$ bilhões no ano. O número de omissos atingiu 11,7 milhões de pessoas, somando uma movimentação financeira de R\$179,4 bilhões. A concentração dos recursos movimentados por pessoa nesses dois grupos foi, entretanto, fortemente desigual: apenas 62 pessoas declaradas isentas tinham movimentado R\$ 178 milhões em 1998. Das omissas, 139 pessoas movimentaram $\mathrm{R} \$ 28,9$ milhões.

Em relação ao grupo dos contribuintes do imposto de renda, o cruzamento com os dados da CPMF permitiu à Receita Federal construir o indicador movimentação financeira/rendimento declarado que sugere a magnitude aproximada de rendimentos não declarados. $\mathrm{O}$ indicador deve, evidentemente, ser corrigido pelo número de movimentações para gerar uma informação mais precisa. Para o ano de 1998, as pessoas físicas declarantes de imposto de renda movimentaram $\mathrm{R} \$ 1,3$ trilhão e pagaram $\mathrm{R} \$ 314,3$ bilhões como imposto de renda, gerando o valor de 4,2 para o indicador da Receita. No caso das pessoas jurídicas, o indicador assumiu valores menores do que para as pessoas físicas e estava inversamente relacionado com o tamanho da empresa. Assim, as empresas que declararam receita por meio do simples obtiveram um indicador de 3,9, as empresas sob regime do lucro presumido atingiram um indicador de 2,04, enquanto aquelas sob o regime do lucro real tiveram um indicador de 1,61.

Entre 2001 e 2007, a existência da CPMF possibilitou a consolidação da prática do cruzamento dessas informações, cujo papel no combate à sonegação fiscal foi preservado mesmo após a extinção da CPMF. Em dezembro de 2007, a Receita Federal, por meio da Instrução Normativa $n^{\circ} 802,{ }^{29}$ tornou obrigatório o fornecimento semestral pelas instituições financeiras de informações a respeito de operações que ultrapassassem $R$ \$ 5 mil para pessoa física e $R$ \$ 10 mil para pessoa jurídica no acumulado de seis meses. ${ }^{30}$ Os limites são aplicados sobre cada modalidade de um conjunto amplo de operações: compra e venda de títulos de dívida, de ações em bolsa de valores, de títulos nos mercados futuros e de opções, compra de moeda estrangeira, ouro, remessa de divisas para o exterior, saques e pagamentos. No caso de apenas uma operação ultrapassar os limites estabelecidos, a instituição financeira deve fornecer informações a respeito das outras modalidades de operação realizadas pelo agente, mesmo que elas não tenham ultrapassado os limites.

29 Regulamenta a Lei Complementar no 105, que trata do acesso a informações bancárias.

30 Com base na regulamentação da Lei no 105, a Receita Federal já havia criado anteriormente a Declaração de Operações com Cartão de Crédito (Decred), segundo a qual as operadoras de cartão de crédito deveriam enviar as informações à Receita sobre faturas acima de R\$ 5 mil mensais. Com a Instrução Normativa $n^{\circ} 802$, esse limite passa a ser semestral, alcançando um número maior de agentes (FERNANDES; VERISSIMO, 2007). 


\section{Considerações Finais}

A experiência brasileira com a tributação de transações financeiras ilustra a capacidade de esses tributos perseguirem um conjunto relativamente amplo de objetivos. A criação do IOF, na década de 1960, lhe concedia um caráter regulatório, auxiliar das políticas monetária e cambial. Esse aspecto era reforçado, inclusive, pelo destino dos recursos arrecadados com esse tributo, que compuseram "reservas monetárias" sob gestão da autoridade monetária entre 1966 e 1983. A análise do período recente indica, contudo, uma diversificação dos objetivos do IOF. Seu caráter arrecadatório foi reforçado quando elevações de suas alíquotas buscaram compensar a queda de receita ocasionada pela redução ou extinção de outros tributos, como foi o caso em 1999 e 2008, em substituição à arrecadação da CPMF, e novamente em 2011, em função da queda de arrecadação com o reajuste da tabela do imposto de renda retido na fonte.

Desde 2009, três outros objetivos foram conferidos ao IOF. Esse tributo voltou a ser usado como instrumento de controle de capitais, o que esteve estreitamente associado ao cenário de abundante liquidez internacional e elevado diferencial de juros da economia brasileira. Adicionalmente, elevações das alíquotas desse tributo também constituíram instrumento de política macroprudencial, prevenindo uma elevação da exposição ao risco sistêmico dos bancos com a desaceleração do ritmo de expansão do crédito ao consumo e com o desincentivo a captações externas dos bancos. Por fim, com a redução ou eliminação da cobrança de IOF sobre determinadas modalidades de captação de recursos nos mercados de capitais o IOF voltou a ser utilizado como instrumento de política financeira, visando ao desenvolvimento de um mercado secundário de títulos privados de dívida.

Diferentemente do IOF, o objetivo da CPMF foi, desde sua criação, arrecadatório. Entre 2001 e 2007, contudo, um novo papel lhe foi concedido, fazendo do cruzamento de informações sobre as declarações de renda com a arrecadação da CPMF um instrumento eficaz de combate à sonegação fiscal e à lavagem de dinheiro. A consolidação dessa prática de fiscalização no período de vigência da CPMF garantiu sua permanência mesmo após a extinção da contribuição no final de 2007. Ao contrário do que supunham seus críticos, durante a vigência da sua maior alíquota (0,38\%), a CPMF não causou nem desintermediação financeira nem fuga de capitais.

No momento atual, em que os líderes dos principais países discutem a conveniência de tributar as transações financeiras, mediante a imposição de uma taxa Tobin sobre os fluxos internacionais, a experiência brasileira pode fornecer importante subsídios para o debate. De igual modo, outros países podem extrair importantes lições tanto do êxito da $\mathrm{CMPF}$ quanto instrumento de combate à sonegação fiscal e à lavagem de dinheiro como da utilização do IOF como instrumento de 
controle de capitais stricto sensu. O caso brasileiro fornece evidências sólidas que os tributos sobre transações financeiras são ferramentais auxiliares bastantes úteis na regulação dos mercados privados.

\section{Referências}

ALBUQUERQUE, P. Os impactos econômicos da CPMF: teoria e evidência. Brasília, DF: Banco Central do Brasil, jun. 2001. (Trabalho para Discussão, n. 21).

BARBOSA, F. H. O sistema financeiro brasileiro. São Paulo: FGV, [201-?]. Disponível em: <http://www.fgv.br/professor/fholanda/Arquivo/Sistfin.pdf>. Acesso em: 05 out. 2011.

BIANCARELLI, A. Sub-projeto II: abertura, financiamento externo e sistema financeiro doméstico. Relatório 2: o sistema financeiro doméstico e os ciclos internacionais de liquidez. In: Projeto de pesquisa: o Brasil na era da globalização: condicionantes domésticos e internacionais ao desenvolvimento. Convênio BNDES-Cecon-IE-Unicamp, ago. 2007. Disponível em: < http://www.iececon.net/bndes/SubprojetoIIRelat2BNDES.pdf>. Acesso em: 05 out. 2011.

BOLSA DE MERCADORIAS, FUTUROS E VALORES. Informe Técnico de Mercado [2011]. Disponível em <http://www.bmfbovespa.com.br/shared/IframeHotSiteBarraCanal. aspx? altura $=900 \mathcal{E}$ idioma $=$ pt-brËurl $=$ www.bmfbovespa. com.br/informe/default.asp $>$. Acesso em 15 dez. 2011.

BRASIL. Banco Central do Brasil. Sistema Gerenciador de Séries Temporais. [2011e] Disponivel em: < https://www3.bcb.gov.br/sgspub/localizarseries/localizarSeries.do?method $=$ prepararTelaLocalizarSeries $>$. Acesso em: 15 dez. 2011.

. Base de dados econômicos e financeiros do Instituto de Pesquisa Econômica Aplicada. Arrecadação das receitas federais. Secretaria da Receita Federal [2011b]. Disponível em: < http://www.ipeadata.gov.br > Acesso em: 05 out. 2011.

Ministério da Fazenda. Secretaria da Receita Federal. Contribuição provisória sobre movimentação ou transmissão de valores e de créditos e direitos de natureza financeira (CPMF). [2011]. Disponível em: < http://www.receita.fazenda.gov.br/PessoaJuridica/CPMF/ InformacoesCPMF/default.htm\#Recolhimento\%20da\%20CPMF > . Acesso em: 01 set. 2011.

. Ministério da Fazenda. Secretaria da Receita Federal. Decreto $n^{\circ}$ 6.306, de 14 de

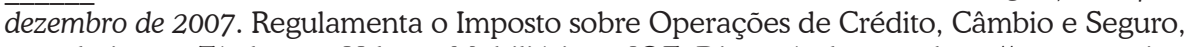
ou relativas a Títulos ou Valores Mobiliários - IOF. Disponível em: < http://www.receita. fazenda.gov.br/legislacao/decretos/2007/dec6306.htm > . Acesso em: 20 dez. 2011.

. Ministério da Fazenda. Secretaria da Receita Federal. Relatórios do Resultado da Arrecadação. [2011c] Disponível em: <http://idg.receita.fazenda.gov.br/dados/receitadata/ arrecadacao/relatorios-do-resultado-da-arrecadacao >. Acesso em: 15 dez. 2011.

BRASIL. Ministério da Previdência Social. Instituto Nacional do Seguro Social. Anuário Estatístico da Previdência Social - Suplemento Histórico (1980-2011). [2011d] Disponível em: $<$ http://www.previdencia.gov.br/arquivos/office/27_130924-151222-748.pdf>. Acesso em: 05 out. 2011. 
BRASIL. Ministério da Saúde. Sistemas de Informação sobre Orçamentos Públicos em Saúde. Gastos da União com Ações e Serviços Públicos de Saúde. [2008]. Disponível em: $<$ http://siops.datasus.gov.br/Documentacao/SIOPS\%20Uni\%C3\%A30\%202007\%20.pdf>. Acesso em: 05 out. 2011.

. Presidência da República. Decreto $n^{\circ} 7.632$, de $1^{\circ}$ de dezembro de 2011 . Altera os arts. 7o e 15-A do Decreto no 6.306, de 14 de dezembro de 2007, que regulamenta o Imposto sobre Operações de Crédito, Câmbio e Seguro, ou relativas a Títulos ou Valores Mobiliários - IOF. [2011a] Disponível em: http://www.planalto.gov.br/ccivil_03/_Ato2011-2014/2011/ Decreto/D7632.htm>. Acesso em: 20 dez. 2011.

CARVALHO, F. C.; SICSÙ, J. Controvérsias recentes sobre controles de capital. In: SICSÙ, J.; FERRARI, F. (Org.). Câmbio e controle de capitais. Rio de Janeiro: Elsevier, 2006. p. 1-28.

CINTRA, M. A. M.; A reestruturação patrimonial do sistema bancário brasileiro e os ciclos de crédito entre 1995 e 2005. In: CARNEIRO, R. (Org.). A supremacia dos mercados e a política econômica do governo Lula. São Paulo: Unesp, 2006. p. 321-346.

COELHO, I.; EBRILL, L.; SUMMERS, V. Bank debit taxes in Latin America: An analysis of recent trends, Washington, DC: International Monetary Fund, May 2001. (Working Paper, n. 167). Disponível em: < http://www.imf.org/external/pubs/ft/wp/2001/wp0167.pdf>. Acesso em: 05 out. 2011.

FARHI, M. Análise comparativa dos regimes de metas de inflação: pass-through, formatos e gestão nas economias emergentes. Campinas: IE/Unicamp. 2007. (Texto para Discussão n. 127). Disponível em: <http://www3.eco.unicamp.br/cecon/images/arquivos/publicacoes/ publicacoes_23_1395270353.pdf >. Acesso em: 05 out. 2011.

. Os impactos dos derivativos no Brasil. In: MARCOLINO, L. C.; CARNEIRO, R. (Org). Sistema financeiro e desenvolvimento no Brasil: do Plano Real à crise financeira. São Paulo: Publisher do Brasil/Atitude Editora, 2010. p. 209-231.

FEDERAÇÃO BRASILEIRA DE BANCOS. Ciab 2011: a tecnologia além da web. 2011. Disponível em <http://www.febraban.org.br/7Rof7SWg6qmyvwJcFwF7I0aSDf9jyV/ sitefebraban/Setor\%20Banc\%E1 rio\%20em\%20N\%FAmeros\%204\%2005\%20\%282\%29.pdf>. Acesso em 05 out. 2011.

FERNANDES, A.; VERISSIMO, R. Governo perde CPMF mas obriga banco a repassar dados de clientes. O Estado de São Paulo, São Paulo, 29 dez. 2007.

FORBES, K. et al. Bubbles thy neighbor: direct and spillover effects of capital control. In: JACQUES POLAK ANNUAL RESEARCH CONFERENCE, 12, 2011, Washington, DC. Proceedings... Washington, DC: Hosted by the International Monetary Fund, 2011. p. 1-45. Disponível em: http://www.imf.org/external/np/res/seminars/2011/arc/pdf/forbes.pdf. Acesso em: 01 dez. 2011

FREITAS, M. C. P. Banco Central e política macroeconômica: o regime de metas de inflação. In: MARCOLINO, L. C.; CARNEIRO, R. (Org). Sistema financeiro e desenvolvimento no Brasil: do Plano Real à crise financeira. São Paulo: Publisher do Brasil/Atitude Editora, 2010p. 177-208. 
FREITAS, M. C. P. Desafios do financiamento de longo prazo no Brasil. São Paulo: Fundap, 2011. (Boletim de Economia da Fundap, n. 4). Disponível em: < http://www.fundap.sp.gov. br/wp-content/uploads/2014/03/boletim_economia_4_desafios_financiamento.pdf > . Acesso em: 05 out. 2011.

Mercado brasileiro de capitais no período 2003-2008: tendências e evoluções. In: BIASOTO J. G.; NOVAIS, L. F.; FREITAS, M. C. P. (Org.). Panorama das Economias Internacional e Brasileira: dinâmicas e impactos da crise global. São Paulo: Fundap, 2009. p. 235-252.

FREITAS, M. C. P. PRATES, D. M. O mercado de crédito no Brasil: tendências recentes. In: BIASOTO J. G.; NOVAIS, L. F.; FREITAS, M. C. P. (Org.). Panorama das Economias Internacional e Brasileira: dinâmicas e impactos da crise global. São Paulo: Fundap, 2009. p. 215-234.

FREITAS, M. C. P. Subprojeto VIII: crédito bancário no Brasil: evolução e transformações institucionais. Relatório II: evolução e determinantes do crédito bancário no período 2001-2006. In: Projeto de pesquisa: o Brasil na era da globalização: condicionantes domésticos e internacionais ao desenvolvimento. Convênio BNDES-Cecon-IE-Unicamp, ago. 2007. Disponível em: <http://www.iececon.net/bndes/SubprojetoVIIIRelat2BNDES. pdf $>$. Acesso em: 05 out. 2011.

HICKMANN, C.; SALVADOR, E. A arrecadação e o destino dos recursos da CPMF. Brasília, DF: Unafisco, 2007. (Nota Técnica 6/2007). Disponível em: <http:/www2.unafisco.org.br/ estudos_tecnicos/2007/nota_tecnica_cpmf.pdf>. Acesso em: 05 out. 2011.

KOYAMA. S.; NAKANE, M. Os efeitos da CPMF sobre a intermediação financeira. Brasília, DF: Banco Central do Brasil, jul. 2001. (Trabalho para Discussão, n. 23).

LOPREATO, F. Evolução da participação estadual na distribuição institucional de renda. 1981. (Mestrado em Economia) - Programa de Pós-Graduação em Economia, Instituto de Economia, Universidade de Campinas, Campinas, 1981.

MARQUES, R. M.; MENDES, A. A luta pelo financiamento as saúde pública brasileira: de 1985 a 2008. In: ENCONTRO NACIONAL DE ECONOMIA POLÍTICA, 15., 2010, Maranhão. Anais... Maranhão: SEP, 2008. Disponível em: <http://www.sep.org.br/ artigos/download? id $=1609$ Etitle $=$ A\%20luta\%20pelo\%20financiamento\%20da $\% 20$ Sa\%C3\%BAde\%20P\%C3\%BAblica\%20Brasileira:\%20de\%201985\%20a\%202008> . Acesso em: 05 out. 2011.

MINSKY, H. Stabilizing an Unstable Economy. New Haven: Yale University Press, 1986.

MODENESI, A. Regimes monetários: teoria e experiência do Real. São Paulo: Manole. 2005.

MORENO, R. Policymaking from a "macroprudential" perspective in emerging market economies. Basel: Bank of International Settlement, Jan. 2011. (Working Paper, n. 336). Disponível em: <http://www.bis.org/publ/work336.pdf> . Acesso em: 05 out. 2011.

MUNHOZ, V. C. V.; SILVA, T. M.. Vulnerabilidade externa e controle de capitais no Brasil: uma análise das inter-relações entre câmbio, fluxos de capitais, IOF, juros e risco-país. In: ENCONTRO NACIONAL DE ECONOMIA POLÍTICA, 16., 2011, Uberlândia. Anais... Uberlândia, editora, 2011. Disponível em: < http://anpec.org.br/encontro/2011/inscricao/ arquivos/000-659e8fab370f62c19854d536e12ae6eb.pdf>. Acesso em: 15 dez. 2011. 
OLIVEIRA, F. A evolução da estrutura tributária e do fisco brasileiro: 1889-2009. Brasília, DF: IPEA, jan. 2010. (Texto para Discussão, n. 1469). Disponível em: < http://www.ipea.gov.br/ portal/images/stories/PDFs/TDs/td_1469.pdf>. Acesso em 15 dez. 2011.

OSTROY, J. et al. Capital inflows: the role of controls. Washington, DC: International Monetary Fund, 2010. Disponível em: < http://www.imf.org/external/pubs/tt/spn/2010/spn1004.pdf>. Acesso em: 05 out. 2011.

PAULA, L. F.; OREIRO, J. L.; SILVA, G. J. C.. Fluxos e controles de capitais no Brasil: avaliação e proposição de política. In: SICSÚ, J.; PAULA, L. F.; OREIRO, J. L. (Org.). Agenda Brasil: políticas econômicas para o crescimento com estabilidade de preços. Barueri: Manole: Fundação Konrad Adenauer, 2003. p. 65-115.

PRATES, D. M. A gestão do regime de câmbio flutuante no Brasil. In: VIANNA, S. T. W.; BRUNO, M. A. P.; MODENESI, A. M. Macroeconomia para o desenvolvimento: crescimento, estabilidade e emprego. Brasília, DF: Ipea, 2010. v. 4. p. 157-212.

. A gestão do regime de câmbio flutuante nos países emergentes. Campinas: IE/Unicamp,

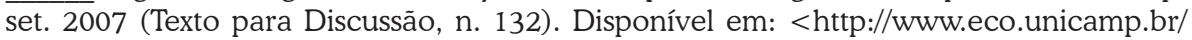
docdownload/publicacoes/textosdiscussao/texto133.pdf> . Acesso em: 05 out. 2011.

. Os fluxos de capitais para a economia brasileira em 2007 e no primeiro quadrimestre de 2008. In: BIASOTO JUNIOR, G.; NOVAIS, L. F.; FREITAS, M. C. P. (Org.). Panorama das economias internacional e brasileira: dinâmicas e impactos da crise global. São Paulo: Fundap, 2009. p. 198-214.

. Dealing with capital flows in the post-crisis context: the Brazilian experience. Campinas, 2011. Disponível em: < http://daadpartnership.htw-berlin.de/fileadmin/Workshops/2011 Campinas/Slide_Shows/Prates_Capital_Flows_Brazil_01.pdf > . Acesso em: 15 dez. 2011.

SÃO PAULO. Fundação para o Desenvolvimento Administrativo. Intervenções macroprudenciais no mercado de crédito e no mercado de câmbio. São Paulo: Fundap, abr. 2011. (Boletim de Economia, n. 3). Disponível em: <http://novo.fundap.sp.gov.br/arquivos/ pdf/Bol3_CE_Intervencoes_macroprudenciais_no_mercado_de_credito_cambio.pdf $>$. Acesso em: 05 out. 2011.

SCHUTTE, G. R. Evolução do debate sobre taxação de fluxos financeiros. In: CINTRA, M. A. M.; SCHUTTE, G. R.; VIANA, A. R. (Org). Gobalização para todos: taxação solidária para os fluxos financeiros internacionais. Brasília, DF: Ipea, 2010. p. 21-43.

SERVO, L. et al. Financiamento e gasto público de saúde: histórico e tendências. In: MELAMED, C.; PIOLA, S. F. (Org.). Políticas públicas e financiamento federal do Sistema Único de Saúde. Brasília, DF: Ipea, 2011. p. 85-108.

SHOME, P. Financial transaction taxes. Beijing: ICRIER, Apr. 2011. (Working Paper, n. 9577). Disponível em: <http://www.esocialsciences.com/data/articles/ Document1184201190.441128.pdf>. Acesso em: 05 out. 2011.

SHOME, P.; STOTSKY, J. Financial transaction taxes. Washington, DC: International Monetary Fund, Aug. 1995. (Working Paper, n. 95/77). 
SILVA, C. R. P.; MARQUES, N.. Movimentação financeira: a base sólida para incidência de um imposto socialmente justo. Brasília, DF: Ipea, ago. 2011. (Texto para Discussão, n. 1.649). Disponível em: <http://www.ipea.gov.br/portal/images/stories/PDFs/TDs/td_1649.pdf>. Acesso em: 05 out. 2011.

SILVA G. J. C.; REZENDE, M. F. C. Eficácia dos controles de capitais no Brasil: uma abordagem teórica e empírica alternativa. Estudos Econômicos, São Paulo, v. 40, n. 3, p. 617-649, jul.-set. 2010.

TORRES, D. et al. Revelando o sistema tributário brasileiro. São Paulo: Edições Sinafesp, 2003.

VIOL, A. L. et al. CPMF:mitos e verdades sob a ótica econômica e administrativa. Brasília, DF: Secretaria da Receita Federal, set. 2001. (Texto para Discussão, n. 15). Disponível em: <http://www.receita.fazenda.gov.br/Publico/estudotributarios/estatisticas/15\%20CPMF\%20 MItos\%20e\%20Verdades.pdf>. Acesso em: 05 out. 2011.

\section{Apêndice A}

Quadro 2 - Evolução das alíquotas da CPMF

\begin{tabular}{|l|l|}
\hline Alíquota & Período de incidência \\
\hline $0,2 \%$ & $\begin{array}{l}\text { De 23 de janeiro de 1997 a 22 de janeiro de } \\
1999 .\end{array}$ \\
\hline Não houve cobrança de CPMF & De 13 de janeiro a 16 de junho de 1999. \\
\hline $0,38 \%$ & $\begin{array}{l}\text { De 17 de junho de 1999 a 16 de junho de } \\
2000 .\end{array}$ \\
\hline $0,3 \%$ & $\begin{array}{l}\text { De } 17 \text { de junho de 2000 a 17 de março de } \\
2001 .\end{array}$ \\
\hline $0,38 \%$ & $\begin{array}{l}\text { De } 18 \text { de março de 2001 a 31 de dezembro } \\
\text { de 2007. }\end{array}$ \\
\hline
\end{tabular}

Fonte: Elaboração própria a partir de Brasil [2011]. 
Tabela 3 - Fontes de recursos do Ministério da Saúde, em \% (de 1995 a 2007)

\begin{tabular}{|c|c|c|c|c|c|c|c|c|c|c|c|}
\hline Fonte & 1997 & 1998 & 1999 & 2000 & 2001 & 2002 & 2003 & 2004 & 2005 & 2006 & 2007 \\
\hline Recursos ordinários & 1,0 & 10,8 & 15,1 & 5,3 & 12,5 & 10,3 & 13,1 & 7,4 & 4,8 & 7,1 & 5,2 \\
\hline Operacões de crédito interna e externa & 0,5 & 1,1 & 1,5 & 2,7 & 2,2 & 1,9 & 1,1 & 0,7 & 0,7 & 0,4 & 0,1 \\
\hline Recursos diretamente arrecadados & 2,4 & 2,6 & 3,5 & 3,3 & 5,1 & 2,7 & 2,3 & 2,2 & 2,4 & 3,1 & 3,7 \\
\hline Títulos de responsabilidade do Tesouro Nacional & 2,8 & 0,2 & 0,3 & 0,2 & 0,3 & 0,4 & 0,5 & 0,0 & 0,0 & 0,0 & 0,0 \\
\hline Contribuições sociais & 72,8 & 71,8 & 61,5 & 80,9 & 74,9 & 81,3 & 82,5 & 88,3 & 91,3 & 88,8 & 87,1 \\
\hline $\begin{array}{l}\text { Contribuição social sobre o lucro líquido - PJ } \\
\text { (CSLL) }\end{array}$ & 19,3 & 8,0 & 13,2 & 12,6 & 7,0 & 22,5 & 27,4 & 32,3 & 39,7 & 40,3 & 38,7 \\
\hline $\begin{array}{l}\text { Contribuição Para o financiamento da } \\
\text { seguridade social }\end{array}$ & 25,6 & 25,9 & 26,3 & 37,1 & 38,5 & 18,6 & 21,1 & 25,2 & 19,2 & 13,5 & 15,4 \\
\hline $\begin{array}{l}\text { Contribuição provisória sobre movimentação } \\
\text { financeira (CPMF) }\end{array}$ & 27,9 & 37,0 & 22,0 & 31,2 & 28,2 & 38,4 & 32,5 & 29,4 & 29,3 & 32,4 & 30,8 \\
\hline $\begin{array}{l}\text { Contribuição para o plano de seguridade social } \\
\text { do servidor }\end{array}$ & 0,0 & 0,9 & 0,0 & 0,0 & 1,2 & 1,9 & 0,8 & 0,9 & 1,2 & 1,0 & 0,9 \\
\hline $\begin{array}{l}\text { Contribuição patronal para o plano seguridade } \\
\text { social do servidor }\end{array}$ & 0,0 & 0,0 & 0,0 & 0,0 & 0,0 & 0,0 & 0,8 & 0,5 & 1,9 & 1,6 & 1,3 \\
\hline Fundo de combate e erradicação da pobreza & 0,0 & 0,0 & 0,0 & 0,0 & 4,5 & 2,4 & 0,0 & 0,9 & 0,3 & 0,0 & 3,0 \\
\hline FSE/FSF & 19,6 & 13,3 & 14,5 & 0,0 & 0,0 & 0,0 & 0,0 & 0,0 & 0,0 & 0,0 & 0,0 \\
\hline Demais fontes & 0,8 & 0,3 & 3,6 & 7,6 & 0,6 & 0,9 & 0,6 & 0,5 & 0,6 & 0,6 & 0,8 \\
\hline Total & 100 & 100 & 100 & 100 & 100 & 100 & 100 & 100 & 100 & 100 & 100 \\
\hline
\end{tabular}

Fonte: Servo et al. (2011).

\section{Apêndice B - Os derivativos cambiais no Brasil}

Como mostra Farhi (2010), surgidos da necessidade de proteção dos agentes em razão da volatilidade dos principais preços macroeconômicos (câmbio e juros), os mercados de derivativos financeiros cresceram com desregulamentação e liberalização financeira, tornando-se instrumento privilegiado de especulação. Em países emergentes com elevado grau de abertura financeira, como é o caso do Brasil, a existência de um mercado de derivativos líquido e profundo, além de permitir operações de arbitragem entre praças diferentes, viabiliza a arbitragem entre os segmentos futuro e à vista do mercado doméstico de câmbio.

Principal mecanismo de transmissão entre a taxa do mercado futuro e a taxa de câmbio à vista, as operações de arbitragem associadas aos derivativos de câmbio estiveram na origem da instabilidade cambial e, sobretudo, da apreciação da taxa de câmbio do real em diversos momentos da história recente da economia brasileira. Duas especificidades do mercado de derivativos brasileiro favoreciam a apreciação do real em momentos de grande afluxo de capital externo, em particular, de investimento estrangeiro de portfólio.

A primeira delas reside no fato de a liquidação dos contratos de derivativos de câmbio não envolver a entrega física de divisas. A legislação em vigor estabelece que a liquidação seja feita em reais pela taxa de câmbio para a pronta entrega. Se tal exigência, de um lado, atenua as pressões de demanda por divisas no mercado à vista em momento de baixa na oferta de moeda estrangeira, por outro lado aumenta a pressão sobre o real em momentos de alta da oferta de divisas.

A segunda é a presença marcante no mercado brasileiro de derivativos cambiais de bancos estrangeiros e de investidores institucionais não residentes, com 
atuação bastante agressiva na realização de operações de arbitragem entre o segmento à vista e futuro do mercado de cambio. Esse tipo de operação, como destaca Farhi (2010, p. 222), "[...] é bastante similar à estratégia de carry trade, também aplicada por investidores estrangeiros e pelos bancos estabelecidos no país, a qual consiste em tomar emprestado na moeda com a menor taxa de juros e aplicar/ emprestar na maior taxa de juros".

Entre 2004 e meados de 2008, a taxa de câmbio do real apreciou-se fortemente, em razão da entrada de volumes crescentes de capital estrangeiro atraído pelas elevadas taxas básicas de juros em um contexto de liquidez abundante. Interrompido em setembro de 2008, quando a crise financeira se aprofundou e assumiu dimensões sistêmicas a partir da falência do Lehman Brothers, o afluxo de investimentos estrangeiros foi retomado em 2009 e ganhou ímpeto em 2010, em razão do expressivo diferencial de juros no mercado doméstico vis-à-vis os mercados internacionais e do maior dinamismo da economia brasileira, resultando novamente em forte apreciação do real frente ao dólar norte-americano.

Nessas duas fases de alta dos fluxos de capitais, o elevado diferencial de juros em um contexto de liquidez abundante suscitou apostas na apreciação da taxa de câmbio do real, as quais se traduziram na ampliação das transações com derivativos, com formação de posições líquidas vendidas em dólar no mercado futuro e arbitragem envolvendo as taxas de câmbio nos mercados à vista e futuro. Ou seja, os investidores vendiam dólar no mercado à vista e compravam dólar no mercado futuro a preços inferiores aos da cotação à vista acrescida da taxa Selic, a taxa básica de juros, para o mesmo período.

A elevação gradual das alíquotas de IOF sobre os investimentos estrangeiros de portfólio a partir de outubro de 2009 para conter a apreciação da moeda brasileira não logrou sucesso. Isso porque, como corretamente assinala Prates (2011), os investidores não residentes intensificaram suas operações de arbitragem no mercado brasileiro de derivativos, assumindo posições de curto prazo em dólar e de longo prazo em reais. As posições opostas às dos investidores não residentes eram assumidas pelos bancos, que, ao mesmo tempo, efetuavam hedge no mercado de câmbio à vista.

Para desestimular esse tipo de operação, o governo decidiu tributar as posições líquidas vendidas em derivativos cambiais acima de US\$ 10 milhões (Decreto $n^{\circ} 7.536$ de 26 de julho de 2011), com imposição de IOF de $1 \%$ (alíquota que pode ser elevada a $25 \%$ ). Como afirma Prates (2011), "[...] essa nova medida introduz areia nas engrenagens das transações cambiais virtuais e reduz os vasos comunicantes entre os mercados onshore e offshore".

Ao lado da tributação dos derivativos, medida que foi crucial para alterar a dinâmica do mercado de câmbio no Brasil, o governo avançou na regulamentação do mercado de derivativos. Além das medidas adotadas em 2009 e 2010, com 
vistas à correção dos problemas de informação e controle, explicitados por ocasião do aprofundamento da crise financeira, quando vieram à tona as dificuldades financeiras de centenas de empresas em operações de crédito bancário vinculadas a contratos de derivativos cambiais, por meio da Medida Provisória $\mathrm{n}^{\circ} 539$ de 27 de julho de 2011, o governo Dilma atribuiu ao Conselho Monetário Nacional $(\mathrm{CMN})$ a responsabilidade pela regulamentação do mercado de derivativos e estabeleceu a obrigatoriedade de registro para todos os contratos de derivativos cambiais, inclusive aqueles negociados em mercados de balcão, nas câmaras de compensação brasileiras, como a BMẺFBovespa e a Central de Custódia e Liquidação Financeira de Títulos (Cetip). ${ }^{31}$ Desde então, o CMN pode intervir nesse mercado, sob a forma de resolução, especificando limites, compulsórios, e características dos contratos de derivativos.

Recebido em: 26/11/12. Aceito em: 16/07/14.

31 A partir de 2008, Cetip S.A., Balcão Organizado de Ativos e Derivativos. 